\title{
DOEFR/ $62449-1$
}

\section{Final Report}

"Marine Biotechnology and Marine Environmental Science Research Program"

Department of Energy Grant Number DE-FG02-97ER62449

Larry Robinson, Principal Investigator

Florida A\&M University

Environmental Sciences Institute

Tallahassee, FL 32307

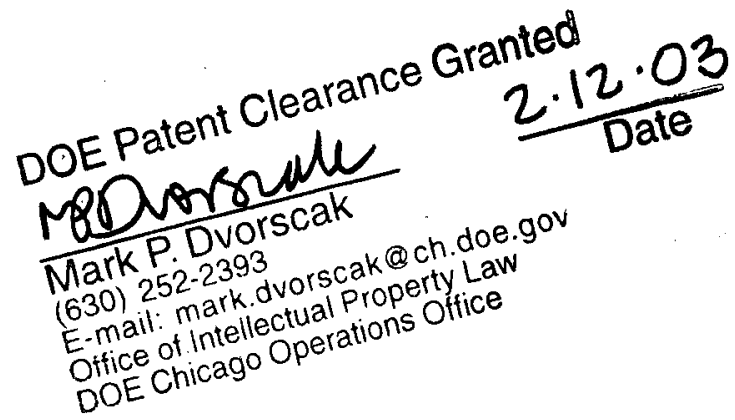




\section{DISCLAIMER}

This report was prepared as an account of work sponsored by an agency of the United States Government. Neither the United States Government nor any agency Thereof, nor any of their employees, makes any warranty, express or implied, or assumes any legal liability or responsibility for the accuracy, completeness, or usefulness of any information, apparatus, product, or process disclosed, or represents that its use would not infringe privately owned rights. Reference herein to any specific commercial product, process, or service by trade name, trademark, manufacturer, or otherwise does not necessarily constitute or imply its endorsement, recommendation, or favoring by the United States Government or any agency thereof. The views and opinions of authors expressed herein do not necessarily state or reflect those of the United States Government or any agency thereof. 


\section{DISCLAIMER}

Portions of this document may be illegible in electronic image products. Images are produced from the best available original document. 


\section{PROGRAM SUMMARY}

The primary goals of this project are to strengthen environmental science academic programs and environmental research capabilities in marine/estuarine science and environmental biotechnology at Florida Agricultural and Mechanical University (FAMU) in order to meet the needs of the Department of Energy (DOE) in environmental science research as well as to supply the nation with a pool of minority scientists qualified to address complex environmental issues. This program will also serve as a catalyst for environmental policy recommendations designed to protect and preserve marine and estuarine environments as well as to reduce adverse health effects from marine pollution. The project's goals have been achieved by involving both faculty and students in research of mutual interest to the Department of Energy's (DOE) Office of Health and Environmental Research. The participants include FAMU faculty and students from the Environmental Sciences Institute (ESI), the College of Arts and Sciences (CAS), and the College of Engineering Sciences Technology and Agriculture (CESTA); Florida State University's (FSU) Departments of Oceanography and Geology; and the University of Georgia's (UG) Department of Geology.

The specific objectives of this project include the development of academic programs; involvement of participants in environmental science research; acquisition of laboratory space and equipment; and implementation of student outreach, recruitment and training programs. This report will provide an update on each of these activities.

\section{Section I: Impact on Academic Programs}

At the inception of this project in the fall of 1997, the Environmental Sciences Institute at FAMU only offered a Masters degree program with 16 full-time, and 12 part-time students. Ten upper-division undergraduate and/or graduate students were enrolled in an 18 credit-hour minor in environmental sciences. 
Resources provided through this project were instrumental in attaining approval of bachelor of science and doctorate degree programs in environmental science in 1998 and 1999, respectively (See Table 1). The marine science and biotechnology tracks of the MS degree program were enhanced with the addition of approximately $7000 \mathrm{sq} \mathrm{ft}$ in laboratory space and nearly $\$ 2$ million in equipment procured in this project and related projects. Concentrations in environmental biomolecular sciences, and aquatic and terrestrial ecology concentrations were included in the Ph.D. degree program along with a variety of related courses often taught by faculty, post-doctoral fellows, and research associated funded through this project. At the bachelorate degree level at FAMU along, 52 students received full or partial academic support from this project. Student enrollment in the BS degree rose sharply from about twenty in the fall of 1998 to over sixty in 2001 . The project has had a similar impact on enrollment in the graduate program. After only two years, enrollment in the Ph.D. program grew to approximately 15 students. Of these 15 students over $50 \%$ entered at the MS level as a result of prior support from this DOE project. A summary of student and post-doctoral participation in this program is shown in Table 2.

The impacts of this program extended into the personnel ranks as well. In 1997, ESI staff included only 1.5 FTE state funded ("hard money") positions. Presently, the Institute has nine state-funded tenure track faculty positions and five state funded staff positions. Commitments have been made to increase staffing level of the Institute as necessary to accommodate student enrollment growth in various degree programs. With impetus from this project these personnel additions worked collaboratively to develop marine/biotechnology related courses shown below in Table 3. 


\begin{tabular}{|c|c|c|c|c|c|}
\hline \multicolumn{6}{|c|}{ Table 1: FAMU Environmental Science Degree Programs } \\
\hline $\begin{array}{l}\text { New (1999) } \\
\text { Ph.D. Program } \\
\text { 80 Credit Hours }\end{array}$ & $\begin{array}{c}\text { Environmental } \\
\text { Biomolecular } \\
\text { Sciences }\end{array}$ & \multicolumn{3}{|c|}{$\begin{array}{l}\text { Environmental Chemistry/ } \\
\text { Aquatic and Terrestrial Ecology }\end{array}$} & $\begin{array}{l}\text { Environmental } \\
\text { Policy } \\
\text { and }\end{array}$ \\
\hline $\begin{array}{l}\text { Existing } \\
\text { M.S. Program } \\
\text { 36 Credit Hours }\end{array}$ & $\begin{array}{l}\text { Environmental } \\
\text { Biotechnology }\end{array}$ & $\begin{array}{l}\text { Environmental } \\
\text { Radiochemistry }\end{array}$ & $\begin{array}{l}\text { Marine } \\
\text { And } \\
\text { Estuarine } \\
\text { Science }\end{array}$ & $\begin{array}{c}\text { Restoration } \\
\text { and } \\
\text { Waste } \\
\text { Management }\end{array}$ & $\begin{array}{l}\text { Environmental } \\
\text { Policy } \\
\text { and } \\
\text { Management }\end{array}$ \\
\hline $\begin{array}{l}\text { New (1998) } \\
\text { B.S. Program } \\
120 \text { Credit Hours }\end{array}$ & $\begin{array}{l}\text { Environmental } \\
\text { Toxicology } \\
\text { And } \\
\text { Risk Assessment }\end{array}$ & \multicolumn{2}{|c|}{$\begin{array}{l}\text { Monitoring } \\
\text { And } \\
\text { Instrumentation }\end{array}$} & $\begin{array}{c}\text { Restoration } \\
\text { and } \\
\text { Waste } \\
\text { Management }\end{array}$ & $\begin{array}{l}\text { Environmental } \\
\text { Policy } \\
\text { and } \\
\text { Management }\end{array}$ \\
\hline
\end{tabular}

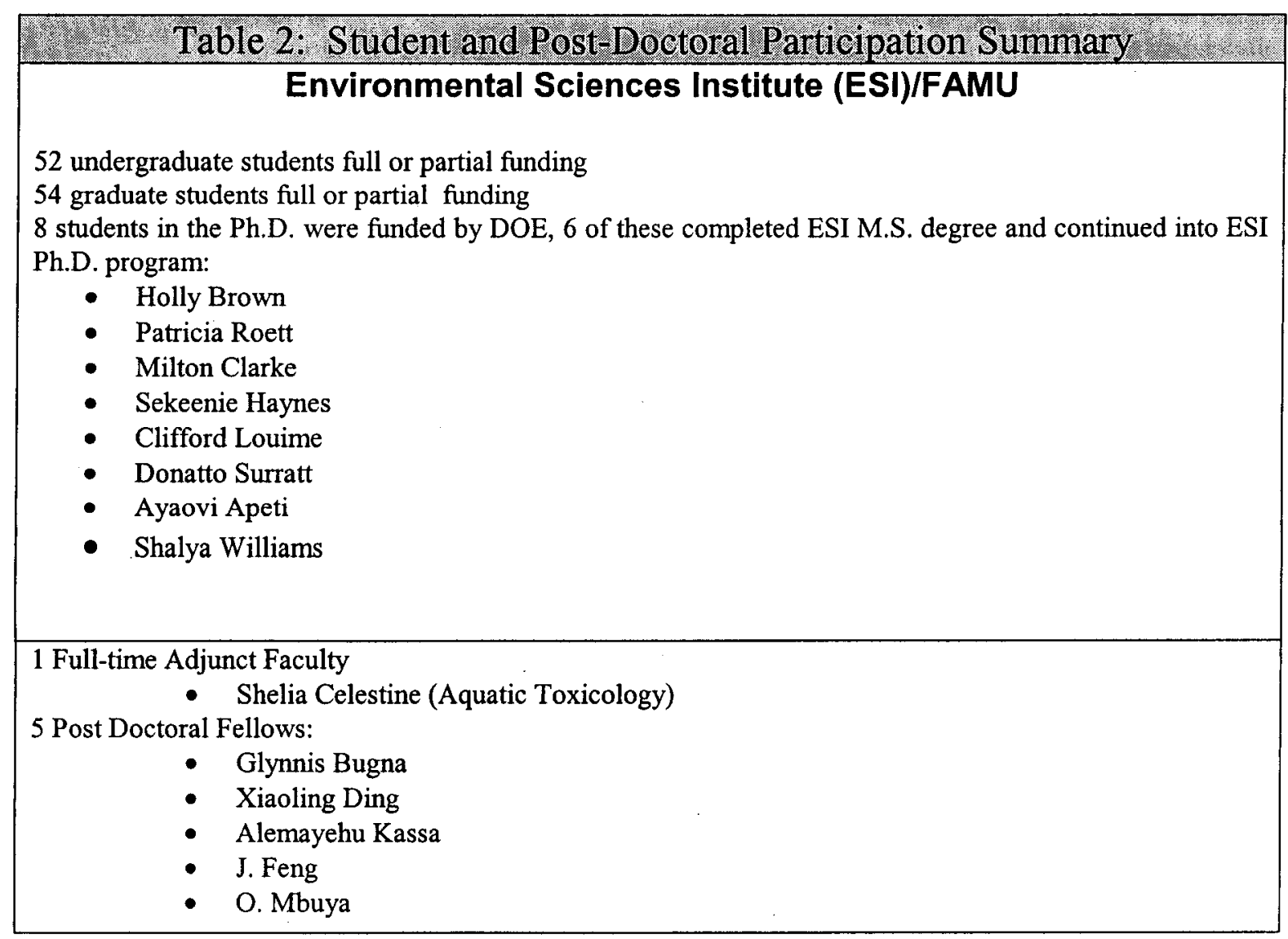




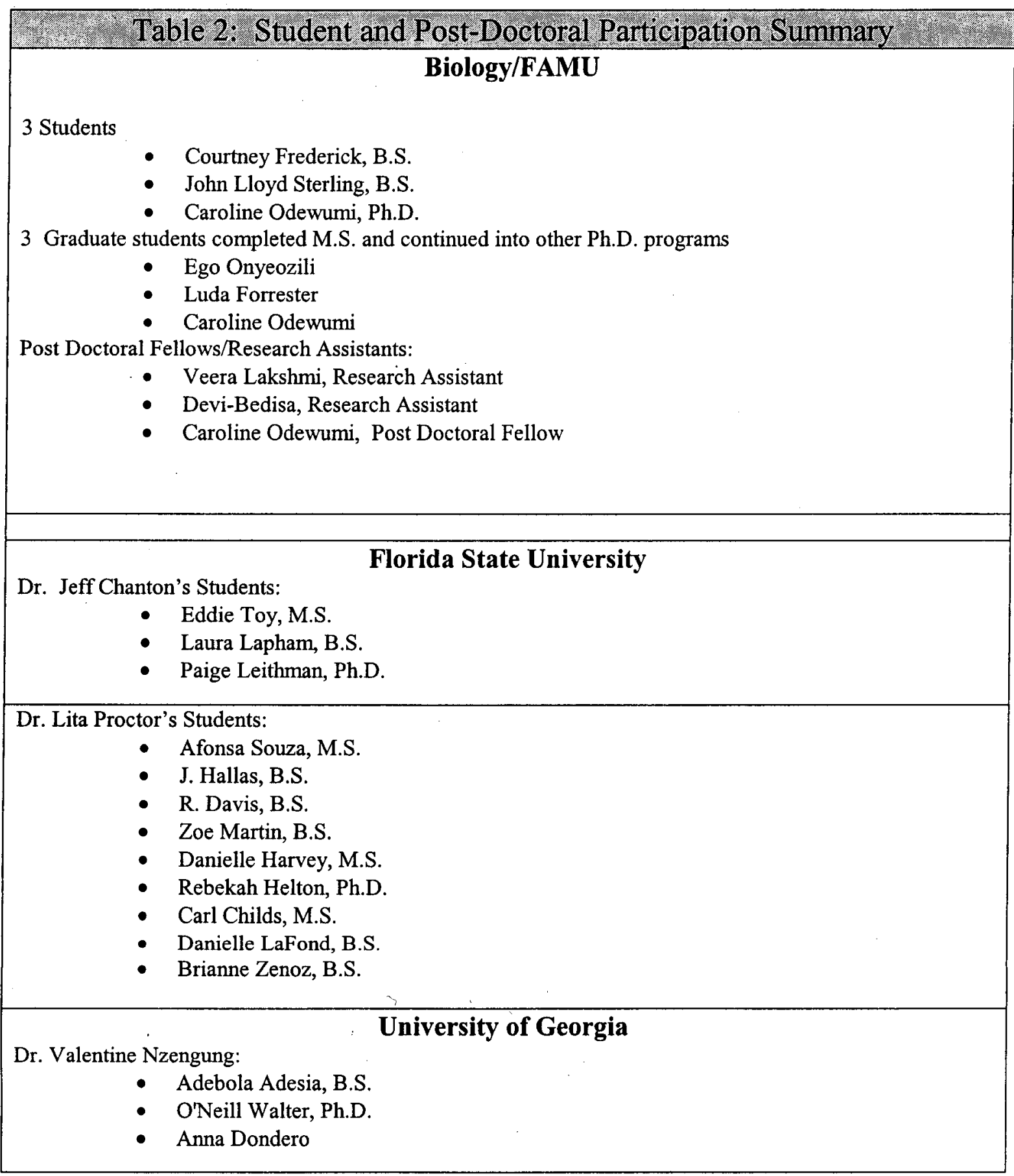




\begin{tabular}{|}
$\begin{array}{l}\text { Table 3: Newly Developed Project Related Courses } \\
\text { (Ail courses offered by FAMU/ESI faculty) }\end{array}$ \\
\hline \multicolumn{2}{|c|}{ Course Prefix, Number, Title } & Credit hours \\
\hline EVS 4025C Applied Microbial Processes W/Lab & 4 \\
\hline EVR 4193C Environmental Monitoring W/Lab & 4 \\
\hline EVS 4024C Marine Microbial Ecology W/Lab & 4 \\
\hline EVR 4215 Marine Pollution & 3 \\
\hline EVS 4027C Wetlands Preserv. \& Restor. W/Lab & 4 \\
\hline EVS 5896 Environmental Biotechnology & 3 \\
\hline GLY 5828 Subsurface Fate \& Transport & 3 \\
\hline EVS 5673 Bioremediation Applications \& Techniques & 3 \\
\hline PCB 5315 Marine/Estuarine Ecosystems & 3 \\
\hline EVS 5068C Marine. Microbial Ecology w/Lab & 4 \\
\hline EVS 5680 Aquatic Toxicology & 3 \\
\hline EVR 6064 Principles of Ecology & 3 \\
\hline
\end{tabular}




\section{Section 2: Research Activities}

A total of six sub-projects defined the primary research focus of this proposal. Collectively, these projects have yielded ten (10) journal articles and over thirty (30) scientific presentations by participants.

\section{Project 1: Sulfate Reduction in Coastal Wetlands: Implications to Environmental Bioremediation; Y. P. Hsieh, J. Feng, L. Robinson, and $M$. Abazinge}

We have evaluated experimental sites in St. Marks salt marsh of Florida. Sediment samples were collected by PVC pipe to a depth of $36 \mathrm{~cm}$ from the middle marsh and high marsh. We monitored the sulfate reduction rates in different seasons of the year and evaluated the relationships of sulfate reduction rate in different depth of the sediment and different seasons. The sulfate reduction rates of the sediments were determined using a modified ${ }^{35} \mathrm{~S}$ tracer technique based on that of Jorgensen (1978). Briefly, in a $\mathrm{N}_{2}$-filled glove bag, 5$6 \mathrm{~g}$ of sediment fraction sample was put into a snap cap vial. Fifty $\mu \mathrm{l}$ of ${ }^{35} \mathrm{~S}$ (about $5 \mu \mathrm{Ci}$ as $\mathrm{NaSO}_{4}$ ) solution was injected throughout the sample evenly. Then the samples were incubated under $N_{2}$. After 24 to 48 hours, the samples were frozen in a freezer to stop microbial activity. The frozen samples were thawed and assayed for chromium (II) reducible sulfur (CRS) using a diffusion method of Hsieh and Shieh (1997). The ${ }^{35} \mathrm{~S}$ activity of the CRS was counted using a liquid scintillation counter. The sulfate concentration in sediment pore water was determined by an ion chromatography. Sulfate reduction rate was calculated based on the measured ${ }^{35} \mathrm{~S}$ activity after corrected for counting efficiency, the pore water sulfate content, and the total injected ${ }^{35} \mathrm{~S}$ activity. Sulfate reduction rates are shown in Table P1-1. 
Table P1-1. Sulfate reduction rates in St. Marks salt marsh sediment at different seasons.

\begin{tabular}{|c|c|c|c|c|}
\hline \multirow[t]{2}{*}{$\begin{array}{l}\text { Depth } \\
\text { (cm) }\end{array}$} & \multicolumn{4}{|c|}{ 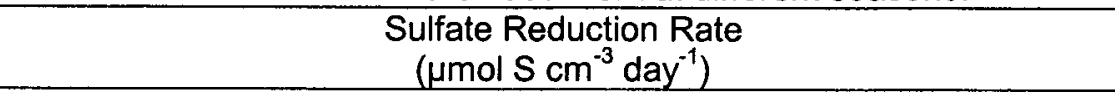 } \\
\hline & $8-22-97$ & $\begin{array}{c}11-12-97 \\
\text { High Marsh }\end{array}$ & $1-29-98$ & $4-23-98$ \\
\hline $0-4$ & 0.158 & 0.094 & 0.061 & 0.484 \\
\hline $8-12$ & 0.05 & 0.013 & 0.017 & 0.087 \\
\hline $16-20$ & 0.014 & 0.01 & 0.004 & 0.037 \\
\hline $24-28$ & 0.038 & 0.006 & 0.007 & 0.022 \\
\hline $32-36$ & 0.038 & $\begin{array}{l}0.011 \\
\text { Middle Marsh }\end{array}$ & 0.003 & 0.013 \\
\hline $0-4$ & 1.161 & 1.131 & 0.359 & 1.787 \\
\hline $8-12$ & 0.284 & 0.145 & 0.08 & 0.363 \\
\hline $16-20$ & 0.076 & 0.06 & 0.049 & 0.104 \\
\hline $24-28$ & 0.073 & 0.052 & 0.027 & 0.063 \\
\hline $32-36$ & 0.028 & 0.046 & 0.02 & 0.03 \\
\hline
\end{tabular}

The primary results showed that the sulfate reduction rates in middle marsh were much higher than that in higher marsh. Sulfate reduction rate was much higher in the top $0-4 \mathrm{~cm}$ than the rest in the depth. The spring season has highest rate and the winter season has lowest rate. The rates of sulfate reduction were increased in the following order in the different seasons: spring, fall, summer, and winter.

We continued the incubation experiments to evaluate the capability of coastal wetlands to remove added hydrocarbons (crude oil) using stable carbon isotope technique. The sediment was collected from a low marsh site of the St. Marks National Wildlife Refuge at the depth of $0-20 \mathrm{~cm}$. The ${ }^{13} \mathrm{C}$ of the sediment was -14 to $-20 \%$ and is distinguishable from that of the crude oil $\left({ }^{13} \mathrm{C}=-27.6\right.$ $\%$ ). Plant residue and roots were removed from the sediment. About $150 \mathrm{~g}$ of the sediment mixed with $2 \mathrm{~g}$ of gypsum powder were incubated under $\mathrm{CO}_{2}$-free conditions. The sediments were treated with crude oil (0.5-3 $\mathrm{g}$ in each bottle) and incubated at ambient temperature with control (sediment w/o crude oil). The $\mathrm{CO}_{2}$ evolved during the incubation was collected by an alkaline trap containing carbonate-free $2 \mathrm{M} \mathrm{NaOH}$. The $\mathrm{NaOH}$ in the trap was withdrawn and replaced with fresh $\mathrm{NaOH}$ periodically. The $\mathrm{CO}_{2}$ trapped by the $\mathrm{NaOH}$ solution was precipitated as $\mathrm{BaCO}_{3}$. The $\mathrm{BaCO}_{3}$ was washed, dried, and weighed. Subsamples of the precipitate were analyzed for $\mathrm{C}-13$ signature. 
The results of ${ }^{13} \mathrm{C}$ analysis are listed in Table $\mathrm{P} 1-2$ :

Table $\mathrm{P} 1-2 .{ }^{13} \mathrm{C}$ signature $\left(\delta^{13} \mathrm{C}, \%\right)$ of the $\mathrm{CO}_{2}$ evolved during incubation.

\begin{tabular}{|c|c|c|c|}
\hline \multirow[b]{2}{*}{ Experiment \# } & \multicolumn{3}{|c|}{ Treatment } \\
\hline & $\begin{array}{l}\text { Incubation time } \\
\text { (days) }\end{array}$ & $\begin{array}{c}\text { control } \\
(\%)\end{array}$ & $\begin{array}{l}\text { +oil } \\
(\%)\end{array}$ \\
\hline \multirow{5}{*}{$J F$} & 4 & -17.61 & -19.43 \\
\hline & 11. & -18.60 & -20.59 \\
\hline & 21 & -18.38 & -20.14 \\
\hline & 33 & -18.34 & -19.78 \\
\hline & 48 & -20.24 & -21.42 \\
\hline \multirow{4}{*}{1} & 12 & $-17.36 \pm 0.14$ & $-20.31 \pm 0.07$ \\
\hline & 21 & $-13.71 \pm 0.02$ & $-18.21 \pm 0.09$ \\
\hline & 28 & $-14.73 \pm 0.23$ & $-18.08 \pm 0.14$ \\
\hline & 41 & $-15.86 \pm 0.07$ & $-21.31 \pm 0.03$ \\
\hline \multirow{3}{*}{ II } & 4 & $-18.18 \pm 0.35$ & $-20.86 \pm 0.19$ \\
\hline & 9 & $-15.71 \pm 0.15$ & $-19.90 \pm 0.09$ \\
\hline & 16 & $-14.56 \pm 0.35$ & $-20.02 \pm 0.73$ \\
\hline \multirow{3}{*}{ Illex } & 4 & $-16.76 \pm 0.07$ & $-20.17 \pm 0.02$ \\
\hline & 11 & $-15.16 \pm 0.07$ & $-20.68 \pm 0.07$ \\
\hline & 18 & $-16.40 \pm 0.02$ & $-21.85 \pm 0.08$ \\
\hline
\end{tabular}

The ${ }^{13} \mathrm{C}$ of the control is in the range of -14 to $-20 \%$ and that of the oil amendment ranged from -18 to $-22 \%$. Using the linear two-end-member mixing model,

$$
\delta^{13} \mathrm{C}_{\text {+oil }}=\mathrm{f}_{\text {control }}{ }^{*} \delta^{13} \mathrm{C}_{\text {control }}-\mathrm{f}_{\text {oil }}{ }^{\star} \delta{ }^{13} \mathrm{C}_{\text {oil }}
$$

where the fractions $f_{\text {hydrocarbon }}$ and $f_{\text {organic matter }}$ represent the percentage contributions by hydrocarbon and soil degradations, respectively, in the total evolved $\mathrm{CO}_{2}$. The calculated crude oil contribution to the $\mathrm{CO}_{2}$ evolution was 16$49 \%$ of the total. The results clearly indicate that crude oil has been effectively degraded in the sediment of the coastal marshes.

Using the ${ }^{13} \mathrm{C}$ technique, we also examined the contribution of sulfate reducers (SRs) on the degradation of crude oil in the marshes. A way to quantify their contribution is through the use of molybdate-amended incubations. The $\mathrm{MoO}_{4}{ }^{-2}$ treatment was intended to block the sulfate reduction activity. Carbon 
dioxide evolution from the incubation was collected and analyzed for the total amount and the ${ }^{13} \mathrm{C}$ signature. Comparisons of evolved $\mathrm{CO}_{2}$ amounts and isotopic signatures between molybdate- and non-molybdate-amended incubations would help us quantify the contribution of the non-sulfate reducers (non SRs) from the total. Contribution of the SRs can then be calculated from the difference. Results of such an experiment are shown below (Table P1-3).

Table P1-3. ${ }^{13} \mathrm{C}$ signature $\left({ }^{13} \mathrm{C}, \%\right)$ of the $\mathrm{CO}_{2}$ evolved during incubation of low marsh soils (Incub. JF) amended with oil (+oil), and with $\mathrm{MoO}_{4}^{-2}$ and oil. Values in parenthesis are total evolved $\mathrm{CO}_{2}$ amounts (in $\mu \mathrm{mol}$ ) observed in each incubation.

\begin{tabular}{ccc}
\hline $\begin{array}{c}\text { Incubation time } \\
\text { (days) }\end{array}$ & \multicolumn{2}{c}{ Treatment } \\
\cline { 2 - 3 } & +oil & $+\mathrm{MoO}_{4}{ }^{-2}+$ oil \\
\hline 4 & $-19.43(1399)$ & $-19.21(1404)$ \\
21 & $-20.59(1333)$ & $-17.41(903)$ \\
33 & $-20.14(1834)$ & $-11.69(672)$ \\
48 & $-19.78(1752)$ & $-8.27(695)$ \\
\hline
\end{tabular}

Molybdate-amended incubations were ${ }^{13} \mathrm{C}$-enriched compared to those that were not. All $\mathrm{MoO}_{4}{ }^{-2}$-treated samples produced significant amount of methane $\left(\delta^{13} \mathrm{C}\right.$ $=-77 \%$ ). During methane production, isotopic signatures of the $\mathrm{CO}_{2}$ become relatively enriched because of formation of ${ }^{13} \mathrm{C}$-depleted $\mathrm{CH}_{4}$ and ${ }^{13} \mathrm{C}$-enriched $\mathrm{CO}_{2}$ (Boehme et al, 1996). Correcting for the presence of methane in the molybdate-amended incubations, and using the percentage contributions of hydrocarbon degradation to the total evolved $\mathrm{CO}_{2}$ (which range from 16-49\%), we determined the proportions of the SR and non-SR bacteria involved in the degradation (Table P1-4). 
Table P1-4. Amounts of evolved $\mathrm{CO}_{2}$ (in terms of $\mathrm{C}$ ) during incubation (Incub. $\mathrm{JF}$ ) due to hydrocarbon degradation by sulfate reducing (SRs) and non-sulfate reducing (non-SRs) bacteria.

\begin{tabular}{cccccc}
\hline \multirow{2}{*}{$\begin{array}{c}\text { Incubation time } \\
\text { (days) }\end{array}$} & $\begin{array}{c}\text { total } \mu \mathrm{mol} \\
\text { crude oil-C } \\
\text { degraded }\end{array}$ & $\begin{array}{c}\mu \text { mol oil-C } \\
\text { degraded }\end{array}$ & $\%$ degradation & $\begin{array}{c}\mu \text { mol oil-C } \\
\text { degraded }\end{array}$ & \% degradation \\
\cline { 3 - 6 } & 255 & 257 & 101 & 0 & 0 \\
11 & 294 & 207 & 70 & 87 & 30 \\
21 & 350 & 142 & 41 & 208 & 59 \\
33 & 272 & 124 & 46 & 148 & 54 \\
48 & 317 & 95 & 30 & 222 & 70 \\
\hline
\end{tabular}

Blocking of sulfate reducers also started to reduce the carbon dioxide evolution rates after a 3-d incubation. After a 48-d incubation, the carbon dioxide evolution of the $\mathrm{MoO}_{4}^{-2}$-treated samples was reduced to only $30 \%$ of the non$\mathrm{MoO}_{4}^{-2}$-treated samples, indicating the increased role of sulfate reducers in digesting the hydrocarbons.

\section{References:}

Boehme S. E., Blair N. E., Chanton J. P., and Martens C. S. (1996) A mass balance of ${ }^{13} \mathrm{C}$ and ${ }^{12} \mathrm{C}$ in an organic-rich methane-producing marine sediment. Geochim. Cosmochim. Acta 60, 3835-3848.

Hsieh Y. P., and Sheih Y. N. (1997) Analysis of reduced inorganic sulfur by diffusion methods: the improved apparatus and evaluation for sulfur isotopic studies. Chem. Geol. 137, 255-261.

Jorgensen B. B. (1978) A comparison of methods for the quantification of bacterial sulfate reduction in coastal marine sediments. 1. Measurements with radiotracer techniques. Geomicrobiol. J. 1, 11-27. 


\section{Project 2: $\quad$ Contaminant Hydrocarbon Degradation by Indigenous Nearshore Bacterial Populations via Cometabolism and Photo- oxidation; R. Hogg, J. Cherrier, J. Chanton, and R. Gragg}

At FAMU funds were used for support of 3 students (Caroline Jenkins, Holly Brown, and Milton Clarke) each of which worked on a specific aspect of the proposal for their masters thesis project. Caroline Jenkins completed her masters thesis entitled 'Tracing in situ Heterotrophic Utilization of Hydrocarbons Using Stable Carbon and Radiocarbon Abundances' in June 1999. The focus of her research was to determine if stable carbon and radiocarbon abundances could be used to trace in situ bacterial degradation of petroleum hydrocarbons. This was accomplished by comparing and contrasting concentrations and isotopic values of bulk dissolved organic carbon (DOC) and dissolved inorganic carbon (DIC) at a pristine site (Turkey Point, Panacea, FL) and an oilcontaminated site (Bayboro Harbor, St. Petersburg, $F L$ ). Her results showed that petroleum hydrocarbons make up approximately $9 \%$ of the bulk DOC pool at oil contaminated site at Bayboro Harbor (Figure P2-1). Her results also showed that the bacterial population at Bayboro Harbor were utilizing and respiring a carbon source that was significantly more depleted in radiocarbon than the bacterial population at the pristine site at Turkey Point and Perdido Bay (Figure P2-2). A new Ph.D. student, Barbara Hamill, is currently in the process of corroborating the findings of Jenkins et al. (1999) through the analysis of the natural radiocarbon and stable carbon abundances of assimilated bacterial carbon (Cherrier et al. 1999) from assemblages collected from Bayboro Harbor. Once corroborated, these findings together with those of Jenkins (1999) will be submitted to the Journal of Environmental Microbiology for publication.

Clarke (2000) and Brown (2000) evaluated the relative contributions of photo-oxidation and cometabolism, respectively, in the stimulation of hydrocarbon degradation by bacterial assemblages collected from the same 
contaminated site in Bayboro Harbor through a series of parallel closed system bacterial incubations. To evaluate the effects of photooxidation on the rate of hydrocarbon degradation the concentration of bacterial respired $\mathrm{CO}_{2}$ were used as an indicator for the extent of biodegradation of crude oil. After $77 \mathrm{~d}$ incubation, bacterial respired $\mathrm{CO}_{2}$ was about $70 \%$ greater in the photo-oxidized oil treated closed bacterial incubation than the unphoto-oxidized oil treatment. (Figure P23). However, photo-oxidized PHCs initially inhibited bacterial respiration of $\mathrm{CO}_{2}$ (up to $49 \mathrm{~d}$ ), indicating bacterial adaptation to photomodified PHCs. Clarke, graduated in the summer of 2000 . He presented the results of his work at three national conferences, DOE BIOMP Conference (Tallahassee, March, 2000), National Organization of Black Chemists and Chemical Engineers (Miami, April, 2000), and the Florida Marine Biotechnology Summit II (Tampa, October, 2000). The scientific paper under preparation will be submitted to the journal of a Journal Environmental Microbiology in November 2000. Mr. Clarke, received his masters degree this year and is now a Ph.D. student in our environmental science program. He is currently carrying out a series of closed system incubations to evaluate how. cometabolism and photo-oxidation cumulatively impact the rate of hydrocarbon degradation by indigenous nearshore bacterial populations.

To evaluate the relative contribution of cometabolism Brown (2000) monitored both the concentration and isotopic signature of respired $\mathrm{CO}_{2}$ over time. From a simple two component mass balance calculation, using isotopic signatures and concentrations of the respired $\mathrm{CO}_{2}$ (Figures P2-4 and P2-5, respectively) in the closed system bacterial incubations, Brown (2000) found that hydrocarbon degradation was more than three times greater in those incubations amended with pinfish (cometabolite) and crude oil than that observed in incubations amended with oil alone (Figures P2-6 and P2-7 respectively). Brown, who also received her masters degree and enrolled in our Ph.D. program, is currently preparing a manuscript, for publication in the Journal of Environmental 
Microbiology, to present her findings. We expect to submit this manuscript in November of this year

At FSU these funds were used for partial support of two students who used stable isotopes to trace and evaluate variations in hydrocarbon degradation rates. This work resulted in one undergraduate honors Sr. Thesis (Laura Lapham, who is now a PhD student at UNC- Chapel Hill) and one graduate student, Edward Toy, MS Thesis entitled 'Enhancement of Orimulsion Degradation Through the Addition of Natural Subsrates' (E. Toy). Laura Lapham's work has been published in the Journal of Environmental Science and Technology (Lapham et al. 1999).

\section{Grant Related Publications and Presentations}

Clarke M., Gragg R., Cherrier, Ding X., Hogg R., and J. Chanton. (2000). Impact of ultra violet radiation on petroleum hydrocarbon degradation by indigenous marine bacteria. DOE BIOMP Conference (Tallahassee, March, 2000), National Organization of Black Chemists and Chemical Engineers (Miami, April, 2000), and the Florida Marine Biotechnology Summit II (Tampa, October, 2000)

Clarke M. (2000). Impact of solar radiation on petroleum hydrocarbon degradation by indigenous marine bacteria. M.S. Thesis, Florida A\&M University.

Clarke M., Gragg R., Cherrier, Ding X., Hogg R., and J. Chanton. (2000). Impact of solar radiation on petroleum hydrocarbon degradation by indigenous marine bacteria. (In preparation for submission to the Journal of Environmental Microbiology.)(Accepted)

Brown H., Hogg, R. Cherrier, J, Chanton J. Ding X. and R. Gragg. (2000) Isotope study of hydrocarbon degradation by indigenous nearshore bacterial 
populations through co-metabolism. BI-OMP Conference 2000, Tallahassee, FL.

Brown H. (2000) Isotope study of hydrocarbon degradation by indigenous nearshore bacterial populations. M.S. Thesis, Florida A\&M University.

Brown H., Cherrier J., Ding X., Chanton J., and R. Gragg. Isotope study of hydrocarbon degradation by indigenous nearshore bacterial populations. (In preparation for submission to the Journal of Environmental Microbiology.)

Jenkins C. (1999). Tracing in situ heterotrophic utilization of hydrocarbons using stable carbon and radiocarbon. M.S. Thesis. Florida A\&M University.

Jenkins C., Cherrier J., Hogg R., Chanton J., and R. Gragg. (2000). Tracing in situ heterotrophic utilization of hydrocarbons using stable carbon and radiocarbon. BIOMP Conference 2000, Tallahassee, FL.

Lapham, L., L. Proctor and J. Chanton. 1999. Using Respiration Rates and Stable Carbon Isotopes to Monitor the Biodegradation of Orimulsion by Marine Benthic Bacteria, Journal of Environmental Science and Technology, 33, 2033-2039.

Toy E., Chanton J., and J. Cherrier. Enhancement of orimulsion degradation through the addition of natural substrates. BI-OMP Conference 2000, Tallahassee, FL. 


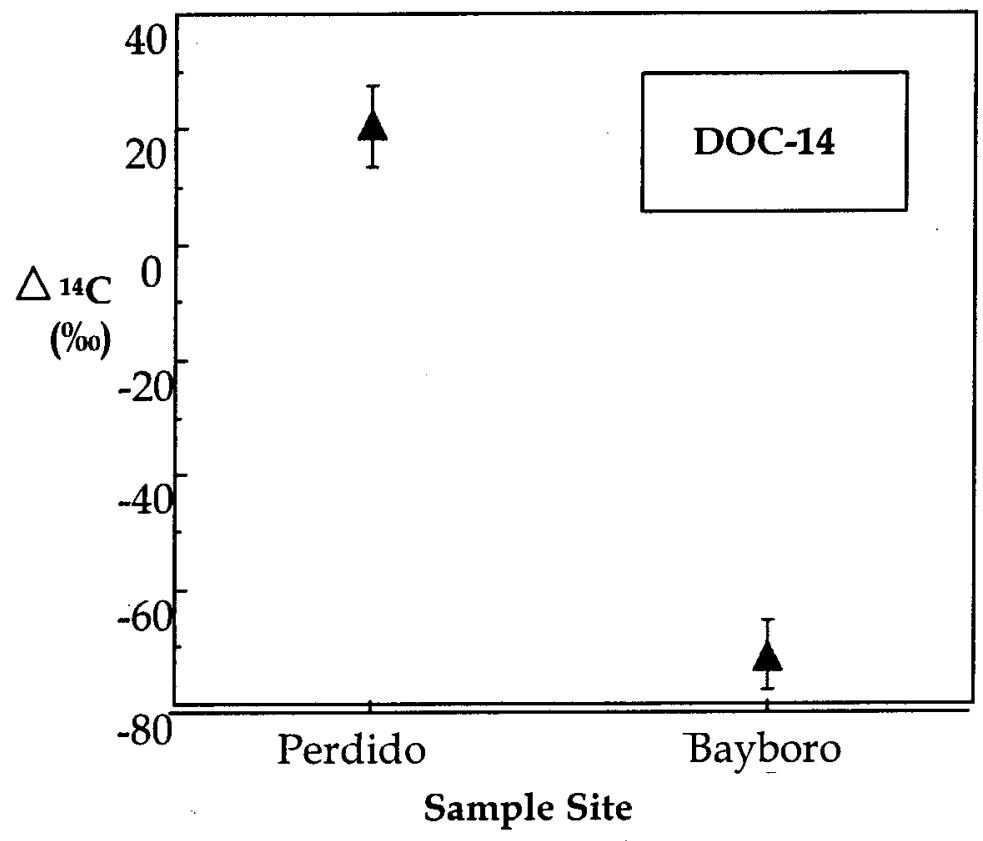

Figure P2-1. Radiocarbon abundances for bulk DOC pools for Bayboro Harbor, Turkey Point and Perdido Bay.

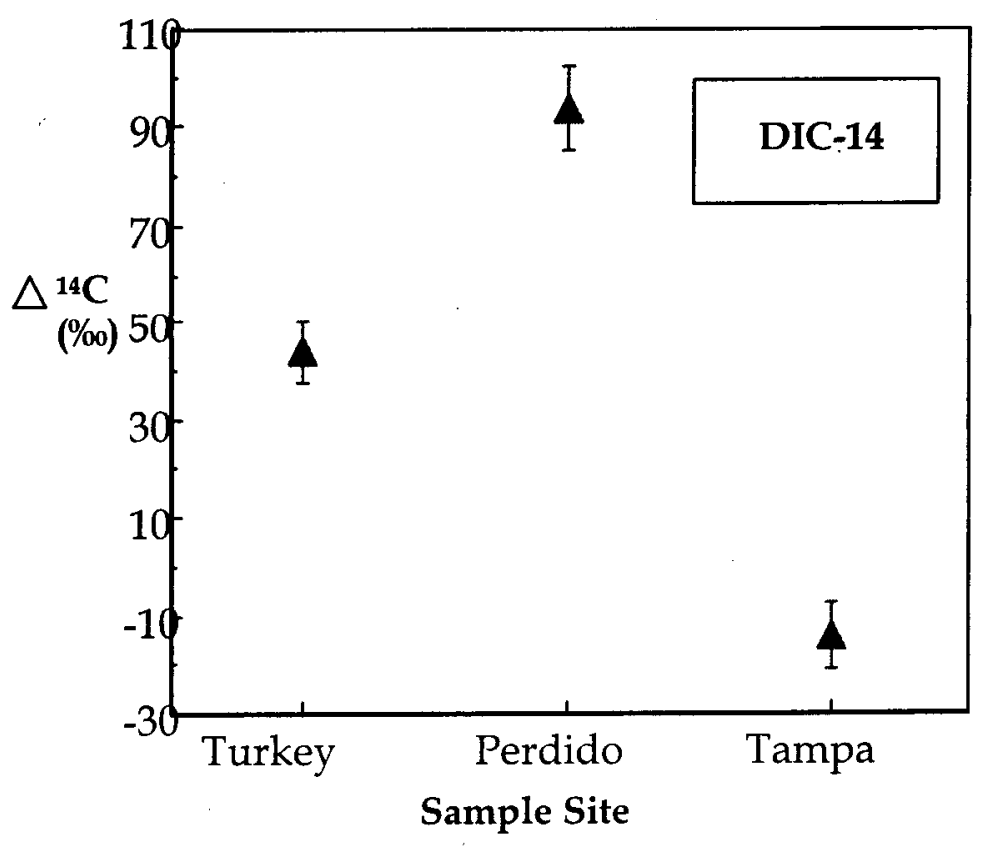

Figure P2-2. Radiocarbon abundances for bulk DIC pools for Bayboro Harbor, Turkey Point and Perdido Bay. 


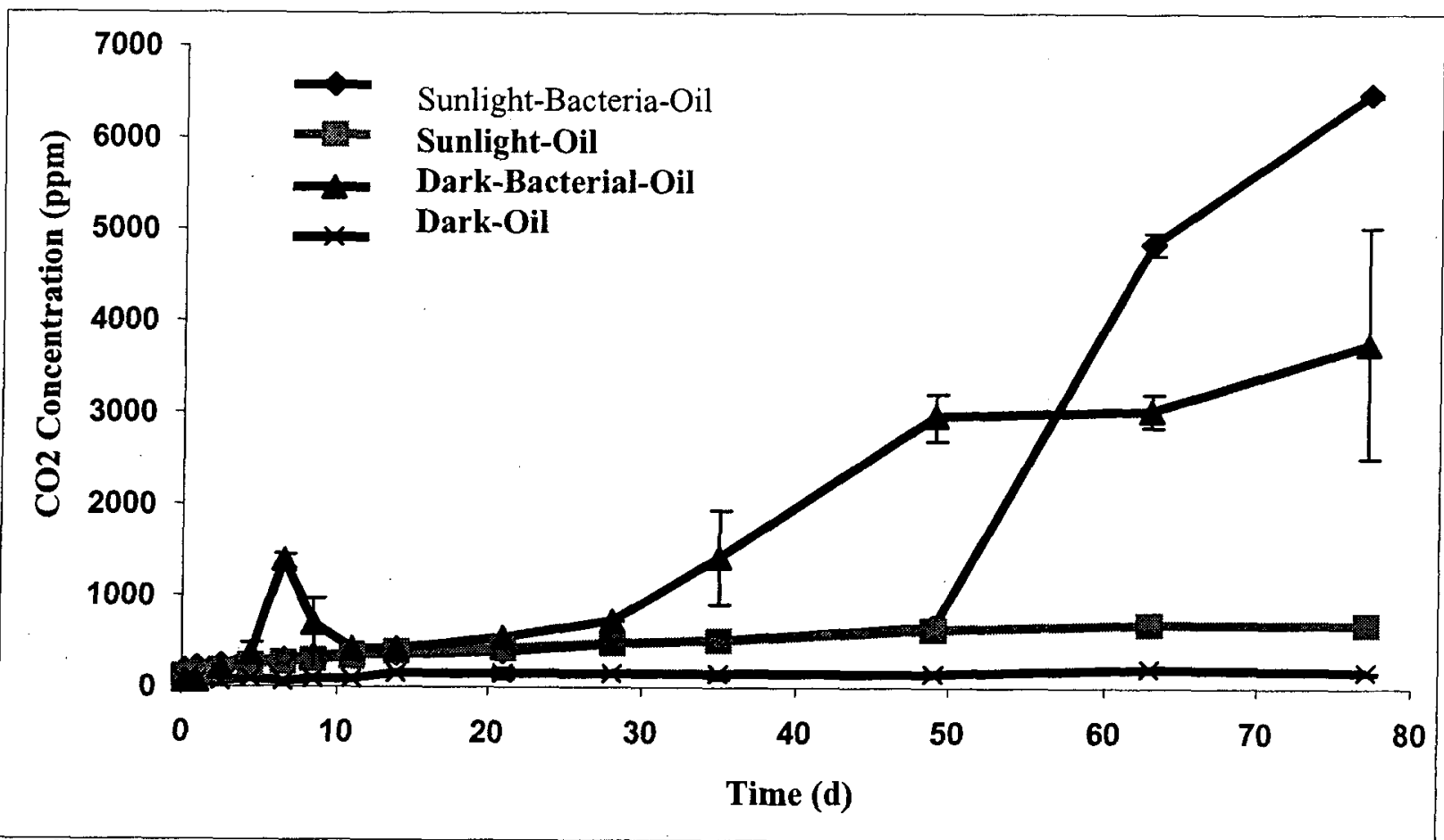

Figure P2-3. Concentrations of bacterial respired $\mathrm{CO}_{2}$ as an indicator for the extent of biodegradation of photooxidized and unphoto-oxidized crude oil in closed system incubations. 


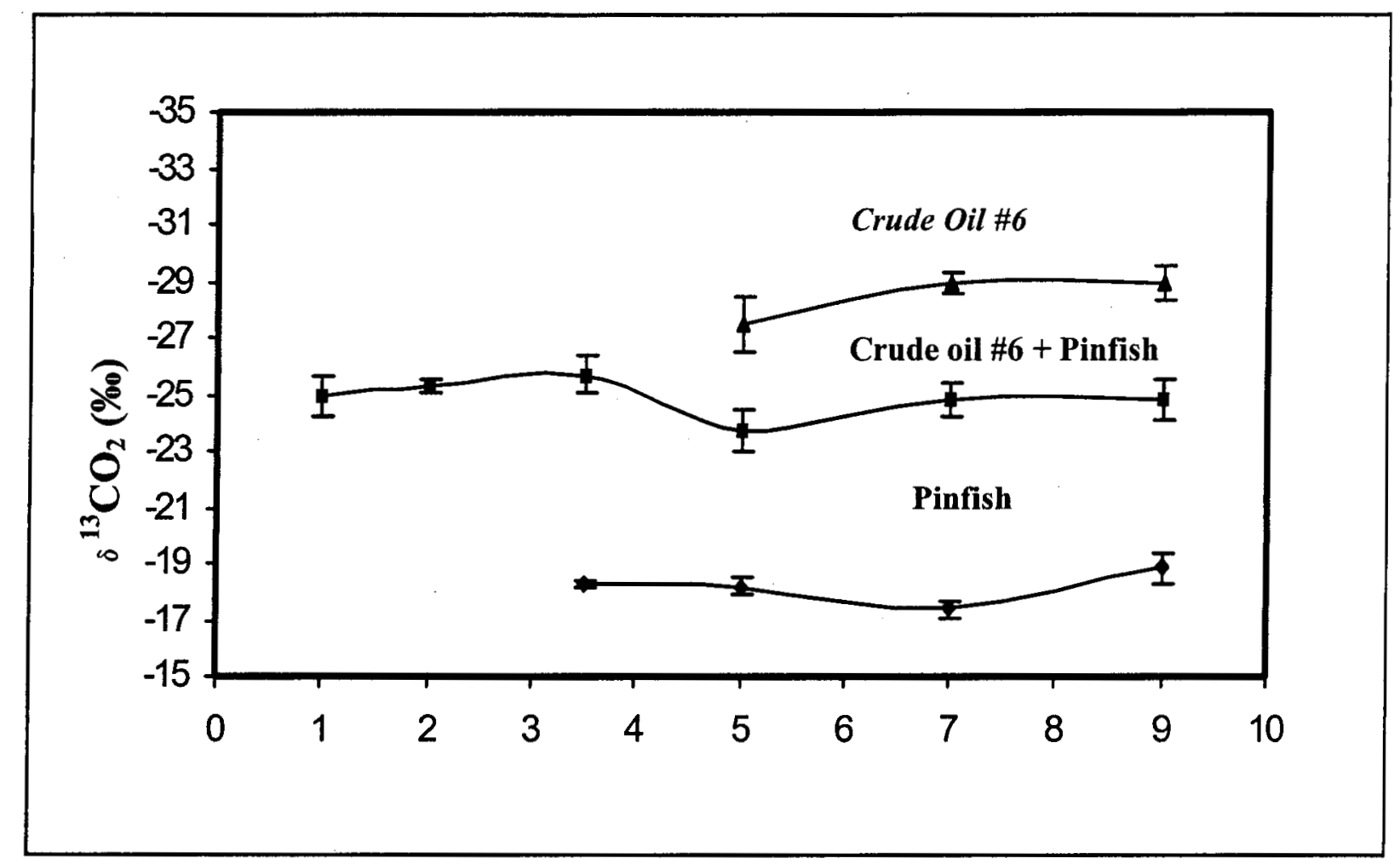

Figure P2-4. $\delta{ }^{13} \mathrm{C}$ values of $\mathrm{CO} 2$ respired by bacterial assemblages in parallel closed system incubation treatments during the course of the 9 day incubation.

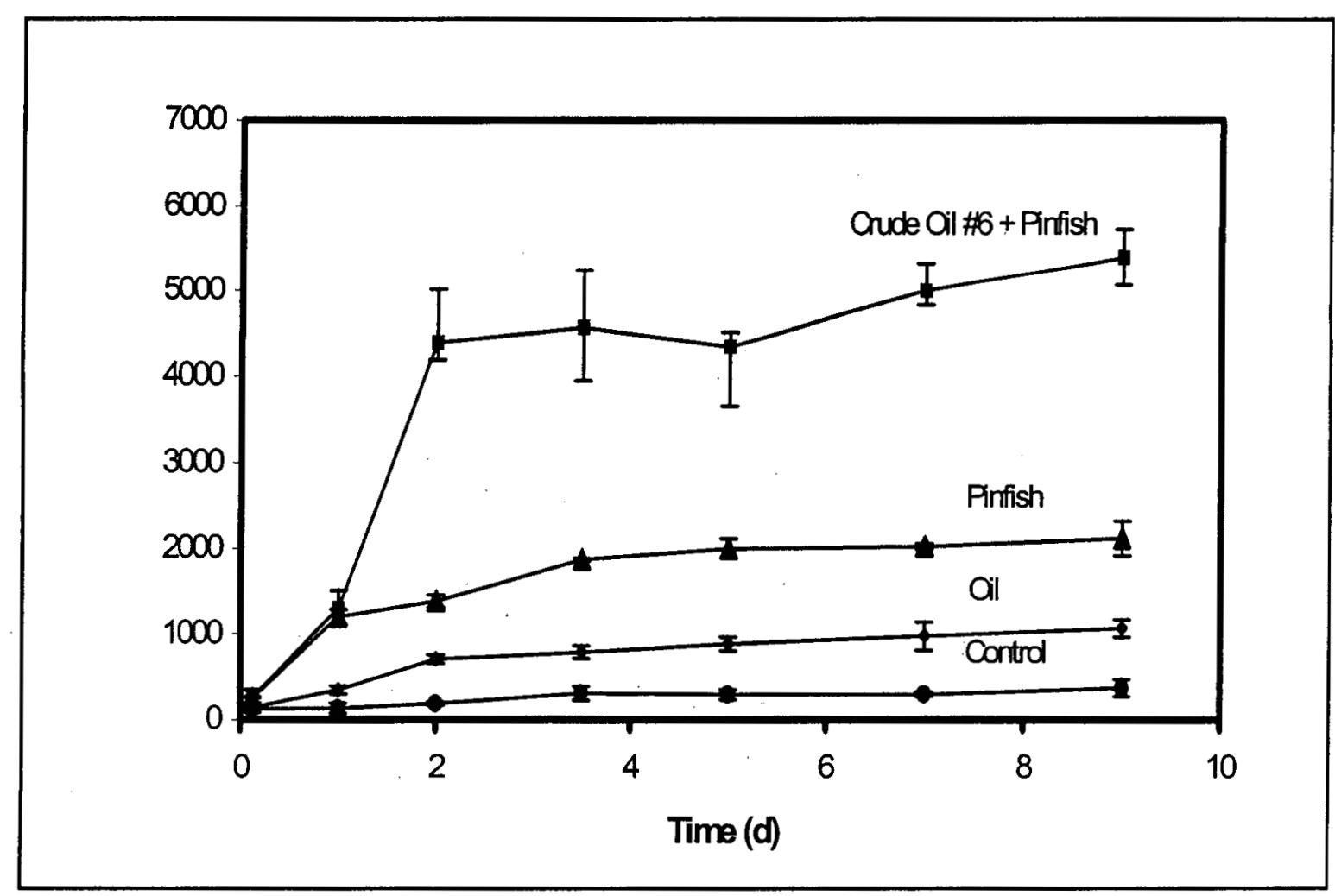

Figure P2-5. Concentration of $\mathrm{CO}_{2}$ respired by bacterial assemblages in parallel closed system incubation treatments during the course of the 9 day incubation. 


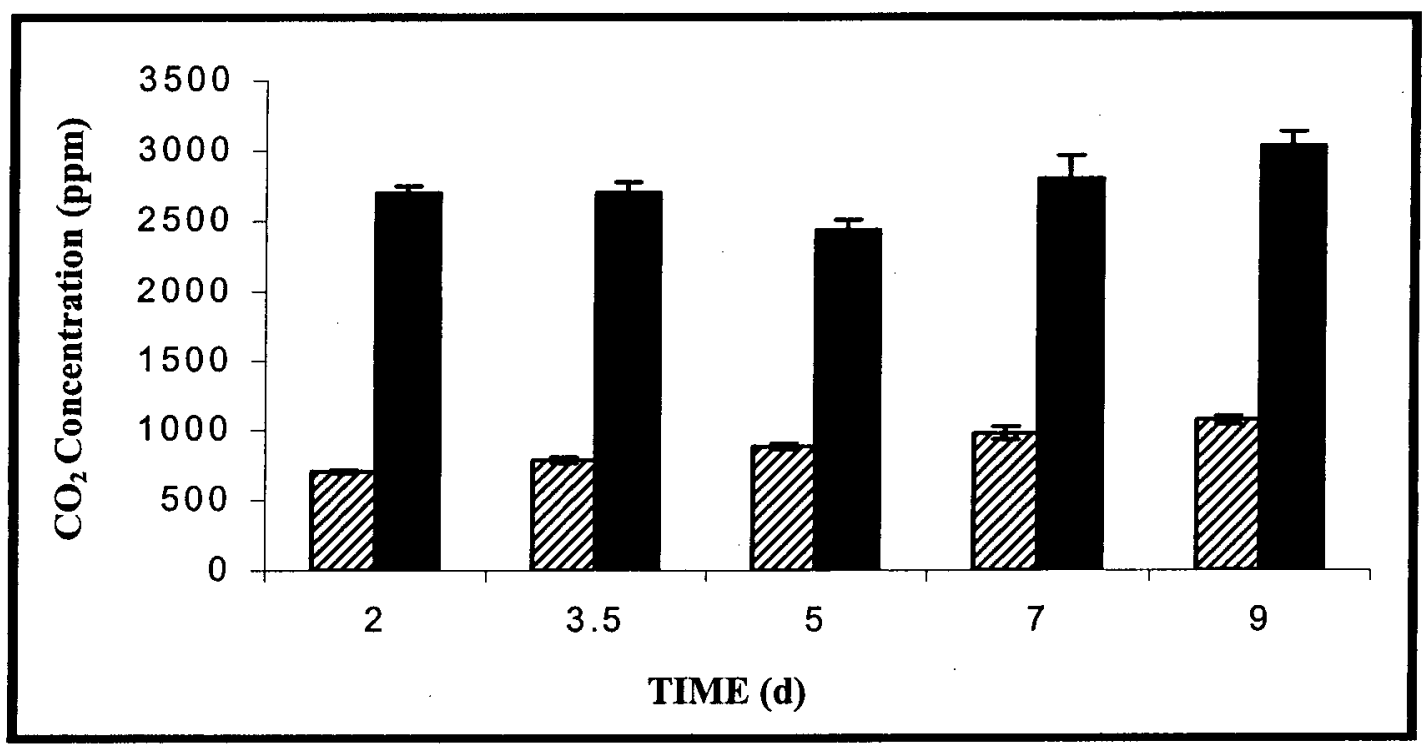

Figure P2-6. Comparison of $\mathrm{CO}_{2}$ generated from the utilization and respiration of oil in crude oil \#6 plus pinfish treatment (solid bars) and the crude oil \#6 alone treatment (cross-hatched bars).

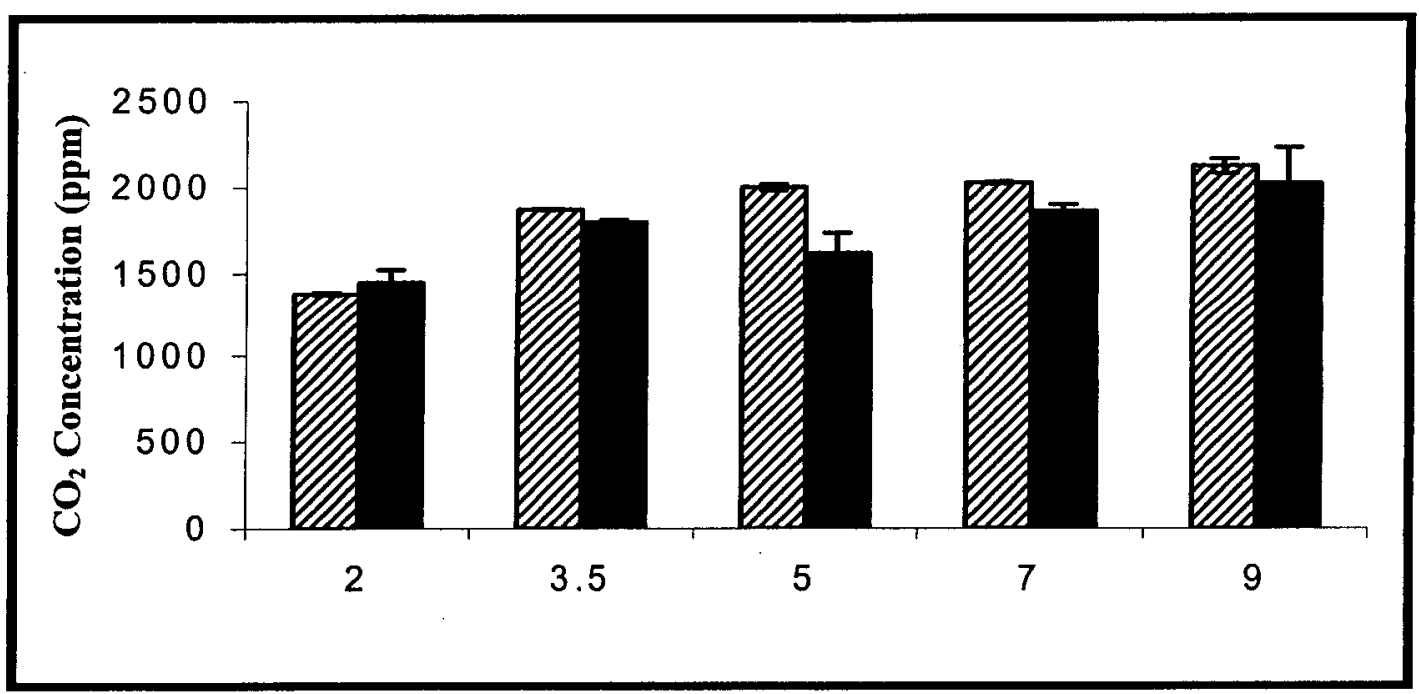

TIME (d)

Figure P2-7. Comparison of $\mathrm{CO}_{2}$ generated from the utilization and respiration of pinfish in crude oil \#6 plus pinfish treatment (solid bars) and the crude oil \#6 alone treatment (crosshatched bars). 


\section{Project 3: Marine Anaerobic Bacterial Communities from Pristine and}

Polluted Environments and their Hydrocarbon Degradation Potential;

L. Proctor and R. Hogg

The coastal environment experiences a high rate of petroleum hydrocarbon pollution, yet few marine bacterial communities have been studied for hydrocarbon-degrading capabilities. In fact, we do not know if hydrocarbondegrading capabilities are inherent properties of all marine bacteria or whether chronic exposure to hydrocarbons creates a selection mechanism for the development of hydrocarbon-degrading bacterial communities. This question becomes important when evaluating the response of coastal habitats to petroleum hydrocarbon pollution. If we find that marine habitats support large populations of marine bacteria with hydrocarbon-degrading potential, this information can be used to promote the growth of hydrocarbon-degrading bacteria in coastal environments to alleviate petroleum pollution.

This project was designed to evaluate the hydrocarbon degradation potential of anaerobic marine bacteria from pristine and polluted marine sediments in Florida by characterizing the general physiologies of the microbial isolates from samples obtained from these areas. Efforts were conducted to evaluate the environmental conditions and functional groups of bacteria which lead to the highest rates of hydrocarbon degradation and to determine the role of bioemulsifier production by marine anaerobes in the degradation of petroleum hydrocarbons. Collectively, these data were used to evaluate the general petroleum hydrocarbon potential of anaerobic bacteria in the marine environment with the aim of developing the anaerobes as bioremediation agents to alleviate oil pollution in the coastal environment. Implementation of this project led to the following products:

\section{Publications:}




\section{Accepted:}

Proctor, L.M. and A.C. Souza. Method for enumeration of 5-Cyano-2,3-ditoyl tetrazolium chloride (CTC)-active cells and cell-specific CTC activity of benthic bacteria in riverine, estuarine and coastal sediments. In press, Journal of Microbiological Methods.

In review:

Childs, C., N. Rabalais, E. Turner, L. M. Proctor. Sediment denitrification in the Gulf of Mexico hypoxic zone. Estuaries.

In preparation:

Harvey, D.M., A. C. Souza and L.M. Proctor. Relationship between RNA content and CTC activity in aerobically- and anaerobically-grown cells of Pseudomonas stutzeri. Environmental Microbiology

Harvey, D. M. and L. M. Proctor. Method for the simultaneous extraction of RNA and DNA from a variety of marine sediments. Applied and Environmental Microbiology

Harvey, D. M. and L. M. Proctor. Diversity of the nitrogenase gene assemblage (nifH) in coastal and shelf sediments and implications for environmental regulation of nitrogen transformations in marine systems. Aquatic Microbial Ecology.

Souza, A.C. and L.M.Proctor. Microbial activity in marine sediments as measured by CTC activity and $\mathrm{CO}_{2}$ production in estuarine and marine sediments. Aquatic Microbial Ecology.

\section{Presentations:}

Invited:

2000 "Denitrification in the seasonal hypoxia zone of the Gulf of Mexico" C. R. Childs, N. Rabalais, E. Turner and L. M. Proctor, In special symposium: "The Hypoxic Zone in the Gulf of Mexico", Society of Environmental Toxicology and Chemistry, Nashville, TN

1999 "Investigating the regulation of denitrification in marine sediments at the molecular level.", Center for Microbial Ecology, Michigan State University.

2000 "Microbial ecology, biogeochemistry, remediation and other studies in coastal sediments.", Department of Civil Engineering, College of Engineering, Florida State University. 
Contributed:

1999 Roett, P., R. Hogg and L. M. Proctor. "Characterization of biosurfactant and bioemulsifier production in response to hydrocarbons in several strains of marine sediment bacteria.", American Society for Microbiology, Chicago, IL.

2000 Childs, C., N. Rabalais, E. Turner and L. M. Proctor, "Sediment denitrification potential in the seasonal hypoxic region on the Louisiana continental shelf.", American Geophysical Union/Ocean Sciences, San Antonio, TX.

2000 Harvey, D., A. Souza, J. Hallas and L. M. Proctor, "Relationship of growth conditions with various measures of activity in Pseudomonas stutzeri: Ecological implications for marine benthic bacteria.", American Society for Microbiology, Los Angeles, CA.

2000 Souza, A. and L. M. Proctor, "Improved method for enumeration of deep-sea and coastal sediment bacteria with estimates for \% CTCactive bacteria.", American Society for Microbiology, Los Angeles, CA.

2000 "Using molecular approaches to study benthic bacterial communities in marine sediments." DOE: Biotechnological Investigations-Ocean Margins Program 2000 (BIOMP 2000)

2000 D. Harvey, C. Childs, L. Latinwo and L. Proctor, "Preparing total nucleic acids (TNA) for molecular analyses of benthic bacterial communities in marine sediments.", BIOMP 2000.

2000 D. Harvey, R. Davis, L. Latinwo and L. Proctor, "Amplification of nifH (nitrogenase gene), $c d_{1}$-nir (cytochrome $c d_{1}$-type nitrite reductase) and Cu-nir (copper-containing nitrite reductase) from Gulf of Mexico estuarine, coastal and continental shelf sediments.", BIOMP 2000.

2000 C. Childs, J. Chanton and L. Proctor, "Regulation of sediment denitrification in the Gulf of Mexico seasonal hypoxic zone.", BIOMP 2000.

2000 A. Souza, R. Hogg, L. Latinwo and L. Proctor, "Enumeration of marine sediment bacteria and estimates of the active fraction of bacteria in coastal and continental shelf sediments.", BIOMP 2000.

2000 H. Basida, D. Harvey, C. Fasanya-Odewum, L. Latinwo and L. Proctor, "Presence of nir and nif DNA and nir and nif transcripts in 
Gulf of Mexico coastal and continental shelf sediments.", BIOMP 2000.

2000 J. Hallas, D. Harvey, J. Chanton and L. Proctor, "Nitrogen fixation potential in enrichments of surficial sediments from the Gulf of Mexico hypoxic zone.", BIOMP 2000.

\section{Student production:}

Graduate students:

Mr. Carl Childs, M.S. Oceanography, 2000. Thesis: Denitrification in surficial sediments of the Gulf of Mexico seasonal hypoxic zone.

Ms. Patricia Roett, (FAMU) M. S. Environmental Sciences, 2000, co-advisor with R. Hogg, (FAMU). Thesis: Biosurfactant production and other physiological strategies for hydrocarbon degradation in isolates of marine sediment bacteria. 
Project 4: Biochemical And Molecular Aspects Of Surface And Sediment Hydrocarbon Degradation By Bacterial Populations In Marine And Estuarine Environments; C. O. Ikediobi; L. M. Latinwo and Z. Dhanarajan.

Water samples were taken at a depth of one meter in coastal waters of Bayboro Harbor in Tampa bay for aliphatic and polyaromatic hydrocarbon analysis. Sediment samples obtained at the same locations were supplied by Dr. Proctor's group at FSU. We have worked out a reproducible solvent extraction method for extracting aliphatic hydrocarbons and PAHs from water and sediment samples based on the use of dichloromethane as the principal extracting solvent and with 5-alpha-androstane and p-terphenyl as internal standards for the aliphatic hydrocarbons and PAHs, respectively. An elaborate workup scheme based on adsorption column chromatography with silica gel- alumina $(2: 1 \mathrm{w} / \mathrm{w})$ was developed for sediment PAH extracts. Extracts from water samples did not require further workup before analysis by GC and GC-MS. Chromatographically cleaned sediment extracts and straight dichloromethane extracts from water samples, were analyzed by GC and components identified by GC-MS. The water sample extracts contained neither aliphatic hydrocarbons nor PAHs. In contrast, the sediment extract contained recalcitrant polyaromatic hydrocarbons but no aliphatic hydrocarbons. The following PAHs were found in sediment:

$\begin{array}{lc}\text { Acenaphthylene } & \text { Benzo(g,h,i)perylene } \\ \text { Anthracene } & \text { Dibenzo(a,h)anthracene } \\ \text { Benzo(a)anthracene } & \text { Phenanthrene } \\ \text { Benzo(a)pyrene } & \text { Pyrene } \\ \text { Benzo(b)fluoranthene } & \text { Chrysene } \\ \text { Benzo(k)fluoranthene } & \text { Indenol(1,2,3-cd)pyrene }\end{array}$

All the PAHs identified contain three or more fused aromatic rings which may explain their resistance to degradation in the environment.

\section{Screening of Marine Sediment Bacterial Isolates for PAH Utilization}

Progress has also been made in the identification and characterization of biomolecules possibly involved in hydrocarbon degradation by marine bacteria. Twenty 
bacterial isolates from these marine sediments were systematically screened for their ability to use recalcitrant PAHs as sole sources of carbon and energy. Marine isolates $B 2$, C2, D2, and F2 were screened for fluorene $(125 \mathrm{mM})$ and acenaphthylene $(0.25$ $\mathrm{mM}$ ), by inoculating $50 \mathrm{ml}$ of growth medium with $100 \mathrm{ml}$ of the primary culture. $A$ control was included which consisted of $50.0 \mathrm{ml}$ of the growth medium that received no bacterial treatment. The flasks were incubated in a water bath shaker with constant shaking $(200 \mathrm{rpm})$. Cell growth was monitored spectrophotometrically at $600 \mathrm{~nm}$ at four hours, and then at eight-hourly intervals for fluorene, and every 24 hours for acenaphthylene.

Sixteen isolates: 698 F06M1b, 698 F06M1c, 698 F06M9a, 698 F06M9c, 798TB31 13a, 798TB31 15a, 798TB31 15d, 798TB31 16a, 798TB31 16d, 498BH 21b, $498 \mathrm{BH} 21 \mathrm{c}, 498 \mathrm{BH} 21 \mathrm{~d}, \mathrm{~B} 2, \mathrm{C} 2$, D2, and F2, were screened for anthracene, chrysene, and naphthalene. The growth medium was made up of $50 \mathrm{ml}$ seawater supplemented with $0.1 \%$ yeast extract, $0.1 \%$ ammonium sulphate, and $0.25 \mathrm{mM}$ of each PAH. The growth medium was inoculated with an overnight culture at a ratio of 1:100. Two controls were included, one was the growth medium, with no PAH added which received bacterial treatment (negative control); the other was the growth medium supplemented with PAH but no bacterial treatment (positive control).

Twelve marine sediment bacterial isolates: 698 F06M1a, 698 F06M1C, 698 F06M9b, 798TB31 13b, 798TB31 15a, 798TB31 15c, 798TB31 15d, 498BH 21c, $498 \mathrm{BH} 25 \mathrm{a}, \mathrm{B} 2, \mathrm{C} 2$, and $\mathrm{F} 2$, were also screened for pyrene $(0.25 \mathrm{mM})$, and $1,2-$ benzanthracene $(70 \mu \mathrm{g} / \mathrm{ml})$. In this setup, the PAHs were completely dissolved in DMSO prior to addition to growth medium consisting of sea water containing $0.1 \%$ yeast extract. Cell growth was monitored spectrophotometrically as described above.

Results obtained showed that isolates B2, C2, and D2 exhibited similar growth patterns with maximum cell density after $12 \mathrm{hr}$ of incubation, while F2 showed a slightly different pattern, with maximum growth observed at $28 \mathrm{~h}$. For acenaphthylene, the four isolates showed similar growth patterns with F2 indicating the least potential for using both PAHs as carbon source. Although the other 16 isolates demonstrated growth 
patterns which indicated that they had utilized PAHs very slowly to varying extents, the most dramatic results were obtained with 798TB31 15d, 798TB31 15a and F2. Specifically, isolate 798TB31 15d grew best in pyrene while 798TB31 15a and F2 performed about equally well in pyrene. Isolate F2 appeared to grow best in 1,2benzanthracene. It is on the basis of these results that isolate 798TB31 15d was subsequently used in a more systematic study of pyrene degradation.

Ideally, all studies of PAH degradation by marine organisms should be conducted in seawater. Hence it was important to study how salinity affects PAH solubility. Additionally, virtually all of the encountered published work in this area are either silent on this subject or give solubility data in distilled water. The solubility study was conducted on the following PAHs: acenaphthene, acenaphthylene, anthracene, 1, 2-benzanthracene, 1,2:3,4-dibenzathracene, $1,2: 5,6-$ dibenzantharecene,benzo[a]pyrene, fluorene, naphthalene, phenanthrene, and pyrene. A known amount of each PAH was weighed out, crushed into fine powder, and introduced into $500 \mathrm{ml}$ volumetric flask. The flask was made up to mark with seawater. The content was magnetically stirred for $42 \mathrm{hr}$ to enhance solubility, and filtered under gravity. The filtrate containing the dissolved PAH was extracted $3 X$ with $25 \mathrm{ml}$ of dichloromethane. The combined extract was evaporated near dryness and redissolved in $1 \mathrm{ml}$ of dichloromethane. This was analyzed by GC/FID equipped with a $25 \mathrm{~m} \times 0.25$ $\mathrm{mm}$ (i.d.) DB-5 fused silica column (Supelco), with $\mathrm{He}$ as the carrier gas. Oven temperature was programmed from $40^{\circ} \mathrm{C}$ (with an initial hold of $4 \mathrm{~min}$ ) to $300^{\circ} \mathrm{C}$ at $40^{\circ} \mathrm{C}$ per min and held at $300^{\circ} \mathrm{C}$ for $10 \mathrm{~min}$. A five- point calibration curve was plotted and employed in the quantification of the PAHs.

Results obtained from this solubility study show that these PAHs are much less soluble in seawater than in distilled water. 


\section{Biodegradation of Pyrene by Bacterial Isolate 798TB31 15d}

Having established from screening experiment, that marine sediment bacterial isolates can utilize $\mathrm{PAH}$ as carbon and energy source, and considering that pyrene was the most abundant PAH found in this sediment, a decision was made to carry out a more detailed study of the pyrene degradation by the most promising bacterial isolate, $798 \mathrm{~T} 3115 \mathrm{~d}$.

After a pilot study of pyrene degradation by 798TB31 $15 \mathrm{~d}$ in artificial seawater, it was found that reaction carried out in artificial sea water supplemented with half the concentration of minimal salt media (i.e. ASW/1/2MSM) showed the greatest degradation of pyrene. This medium was therefore used for all subsequent degradation experiments.

To $40 \mathrm{ml}$ of the medium, pyrene pre-dissolved in a minimal amount of DMSO was added to give a final concentration of approximately $106 \mu \mathrm{g} / \mathrm{ml}$ and then sterilized. The medium was inoculated with the overnight culture of 798TB31 15d. The control growth media received no bacterial cells. All cultures were maintained at room temperature with continuous shaking at $50 \mathrm{rpm}$. Initial sampling was carried out at 8 $\mathrm{hr}$ and subsequently at 24-hr intervals for 11 days. To the contents of the sampled flasks were added $25 \mathrm{ml}$ of HPLC-grade acetonitrile to stop cell growth and solubilize pyrene and its metabolites. The resulting mixture was left in a shaker overnight and subsequently centrifuged at $8000 \times \mathrm{g}$ for $15 \mathrm{~min}$. The supernatant organic phase was decanted and aliquots of this was used to obtain UV absorption spectrum as well as separation by HPLC and GC-MS methods. The aqueous phase left behind following removal of organic phase was acidified $(\mathrm{pH} 2.0-2.10)$ and extracted three times with 25 $\mathrm{ml}$ aliquots of dichloromethane. The combined extract was evaporated to near dryness, then redissolved in $200 \mu$ of dichloromethane and subjected to GC-MS analysis.

HPLC analyses were performed with two different instruments. One was a Shimadzu LC-10AD VP Liquid Chromatography HPLC System equipped with a $5 \mu \mathrm{m}$ Partisil 5 ODS-3 WCS analytical column $(4.6 \times 250 \mathrm{~mm})$ and coupled to a SPD-10A VP UV-Vis detector. The other was a Beckman System Gold Programmable Solvent 
Module 125 equipped with the same column as above and a Beckman Detector Module 166, and a Beckman Autosampler 507e. These two HPLC systems were used for separation of pyrene and its metabolites, using a 70:30 (v/v) acetonitrile-water mobile phase in an isocratic run for $20 \mathrm{~min}$. at a slow rate of $1.0 \mathrm{ml} / \mathrm{min}$. UV absorbance was measured at $254 \mathrm{~nm}$.

GC-MS analyses of culture samples from degradation experiments were performed on a Hewlett-Packard 5890 Series II Gas Chromatograph with a HewlettPackard 5972 Series Mass Selective Detector. Compounds were separated on a high resolution gas chromatograph DB-5.625 column $(30 \mathrm{~m} \times) .25 \mathrm{~mm}$ i.d.) with a film thickness of $0.5 \mu \mathrm{m}$ and helium as the carrier gas (linear velocity of $35 \mathrm{~cm} / \mathrm{s}$, and flow of $0.78 \mathrm{ml} / \mathrm{min}$ ). The column temperature was held at $45^{\circ} \mathrm{C}$ (initial value) for $4 \mathrm{~min}$ and then ramped/programmed to $325^{\circ} \mathrm{C}$ at a rate of $10^{\circ} \mathrm{C} / \mathrm{min}$. The mass spectrometer was operated at $180^{\circ} \mathrm{C}$, with a scan range of $35 \mathrm{amu}-450 \mathrm{amu}$, and a scan rate of $\sim 2$ scans/s.

The UV absorption spectrum was taken of re-extracted pyrene at different times during the course of the degradation experiment. These results reveal that significant degradation appeared to have occurred at $264 \mathrm{hr}$ of incubation. This pattern of degradation is supported by results of a parallel time-dependent HPLC analysis of pyrene degradation. Five degradation metabolites of pyrene were revealed by GC-MS analysis along with their molecular ion peaks and major fragment ions. While none of these five metabolites has been unequivocally identified, preliminary analysis of their UV absorption and mass spectra suggests that two of these five might be 1pyrenylsulfate and 1,6-dihydroxypyrene.

4. More than 20 cultures were grown in marine broth in the absence of oil and in the presence of oil. All the cultures were analyzed for differences in their protein content following short exposure to presence of oil in the medium (1day). One of the cultures, which metabolized polycyclic aromatic hydrocarbons was exposed to oil for a longer period of time $(\sim 21$ days). The results are being analyzed. Initial results show that 
there are qualitative differences in their protein content between cultures. However, there seems to be little difference within a culture when treated differently. Steps are underway to study the protein contents following too dimensional polyacrylamide gel electrophoresis.

5. Genomic DNA and/or total RNA were isolated from the 25 isolates grown in the presence of oil. DNA or RNA from each isolate was blotted on membrane and hybridized with naphthalene metabolizing gene probe (naph gene). All isolates' DNA and RNA were found to hybridize at different strength with naphcoding gene probe. In an attempt to clone the naph gene from these isolates, we used naph-designed primers and amplified 642 base pair fragments. These fragments are now being cloned into suitable vectors. 
Project 5: Marine Algae and Aquatic Plants-Mediated Transformation of Organic Pollutants; C.S. Gardner, O.S. Mbuya, C. Ikediobi and V.A. Nzengung

Biodegradation of Naphthalene in Seawater using Selected Marine Algae An experiment was conducted with three species of marine algae, Aghardiella (red), Sphacelaria (brown), and Cladophora (green), to evaluate their ability to degrade naphthalene. The specific objectives were to (1) quantify the amount of naphthalene that was adsorbed to the algae; and (2) determine the amount of naphthalene that was degraded by the algae. Results indicated that adsorption equilibrium of naphthalene was reached after four hours. Naphthalene adsorption isotherms showed that naphthalene adsorbed more strongly to the algae in the order: Aghardiella >Sphacelaria > Cladophora. When the experiment terminated, a comparison with the control and the algae showed that removal of naphthalene from seawater in bioreactors with algal species ranged from $86.4 \%$ to $93.4 \%$, while the control had a $39.4 \%$ disappearance of naphthalene from seawater. Therefore, the net degradation of naphthalene by the respective species would be equal to total degradation minus the control. The decrease in concentration in the control was most probably attributed to volatilization and photodegradation. The difference between the percent disappearance from the control and the solution containing algal species was attributed to degradation by the algae. Removal of naphthalene from the solution by the respective algae were, Sphacelaria $54 \%$, Cladophora $51.3 \%$ and Aghardiella $46.8 \%$. It was concluded that marine algae are capable of degrading polycyclic aromatic hydrocarbons in aquatic environments.

\section{Biotransformation of Naphthalene using Aquatic Plants}

Three plant species Paperbark (Melaleuca spp.), Black Willow (Salix nigra) and Weeping Willow (Salix babylonica), propagated in a greenhouse, were evaluated for their capabilities in biotransforming and degrading naphthalene. Preliminary 
results indicated that removal of naphthalene from the solution phase started after 6 hours of contact with the plants. This continued for the first $24 \mathrm{hrs}$ following introduction of the plant species to the solution during which time there was a sharp decrease in naphthalene concentration. After seven days of exposure, removal of naphthalene from the solution phase was 75,69 , and $67 \%$ for Black Willow, Weeping Willow, and Paperbark respectively. Comparatively, the control, which had no plant species, had a $51 \%$ Naphthalene removal from the solution. Therefore, the net degradation of naphthalene by the respective species would be equal to total degradation minus the control. The disappearance of naphthalene from the control may be attributed to photolysis, adsorption and evaporation. This experiment is being continued with a replicated study in order to confirm the preliminary findings.

Transformation of Tetrachloroethylene and Trichloroethylene Using Mixed Species Microbial Mats and Algae

Sealed batch and bioreactor experiments conducted with mixed species microbial mats indicated that dissolved PCE and TCE will partition from the aqueous phase and sorb to microbial mat in less than 15 minutes. Sorption equilibrium was attained within approximately 12 hours (O'Niell et al., 1998). This rapid uptake was followed by transformation. Measurements of DO and Eh in the bioreactor indicated that the amount of light available to the mats affected mat health and controlled the development of aerobic and anaerobic zones within the mats.

The bioreactor data confirmed that under natural light conditions PCE was degraded and mat health was maintained in sealed bioreactor chamber. Dissolved phase PCE at an initial concentration of $10 \mathrm{mg} / \mathrm{L}$ was decreased less than $1 \mathrm{mg} / \mathrm{L}$ in 37 days and to non-detectable levels in 84 days. Reducing conditions $(E h=-450 \mathrm{mV}$ ), which are favorable to the degradation of PCE and TCE, developed in the bioreactor at night, and oxidizing conditions ( $\mathrm{Ch}=250 \mathrm{mV}$ 
and $\mathrm{DO}=12 \mathrm{mg} / \mathrm{L}$ ) which are favorable to the degradation of TCE, DCE and VC, developed during the day.

A reductive dehalogenation pathway was indicated by the detection of TCE in samples dosed with PCE, and an oxidative transformation pathway was suggested by the detection of chloroacetic acids in batch vials exposed to light intensities greater than $120 \mu$ mols s $~^{-1} \mathrm{~m}^{-2}$. The presence of DCAA and only traces of TCE suggest the existence of oxidative degradation of PCE metabolites in the bioreactor. The occurrence of multiple degradation pathways in a system offers the potential to minimize the production of hazardous metabolites of PCE and TCE, which may occur if sequential reductive dehalogenation were the only degradation mechanism.

Table P5-1 shows that an $87 \%$ mass balance was achieved using $\left[{ }^{14} \mathrm{C}\right]$ TCE as a tracer. After 30 days, $50 \%$ of the ${ }^{14} \mathrm{C}$-activity measured in the reactor was attributed to TCE, and $37 \%$ was either bound to the mat or was transformed to a metabolite. Approximately $26 \%$ of the liquid phase activity was attributed to ${ }^{14} \mathrm{CO}_{2}$, but it was not possible to measure ${ }^{14} \mathrm{CO}_{2}$ in the mat phase. The $13 \%$ of the original $\left[{ }^{14} \mathrm{C}\right] \mathrm{TCE}$ mass that was not detected may be due to sampling losses, ${ }^{14} \mathrm{CO}_{2}$ in the vapor or mat phases, and volatile compounds released when the mat was acidified.

Because the mats are able to sorb and degrade PCE and TCE, there is promise for their use in a treatment system for wastewater contaminated with these compounds. The same microbial mats have been shown in recent studies at UGA to degrade perchlorate very rapidly. Thus, the mats can be used to remediate water polluted by both organic and inorganic chlorinated compounds. This offers great promise in the remediation of especially mixed contaminants of chlorinated organic solvents and perchlorate. Many species of marine algae 
have also shown great promise in the metabolism of chlorinated organic solvents dissolved in water. 
Table P5-1. Mass Balance Results for Sealed Bioreactors

\begin{tabular}{|l|c|c|c|}
\hline & \% Total Activity & \% TCE Other \\
\hline Total Chamber Liquids & $51.7 \pm 8.0$ & 23.3 & 28.4 \\
\hline Extractable Chamber Solids & $15.6 \pm 0.78$ & 9.8 & 5.7 \\
\hline Chamber Vapor & $1.7 \pm 0.03$ & 1.7 & 0 \\
\hline Sorbed to Chamber & 15 & 15 & 0 \\
\hline Bound to Mat & $2.8 \pm 0.48$ & Unknown & 2.8 \\
\hline Sum & $86.8 \pm 7.72$ & 49.8 & 37 \\
\hline
\end{tabular}

\section{PUBLICATIONS}

Brown, C. M., C. S. Gardner, O. S. Mbuya, C. Ikediobi, and A. Kassa. Biodegradation of Naphthalene in Seawater using Selected Marine Algae. (In Preparation)

Brown, C. M., C. S. Gardner, O. S. Mbuya, and C. Ikediobi. 2000. Biodegradation of Naphthalene in Seawater using Selected Marine Algae. Poster presented at BI-OMP 2000 Conference, Florida A\&M University.

Brown, C.M. 2000. Degradation of Napthalene in seawater using marine algae. MS Thesis Environmental Sciences Institute, Florida A\&M University.

O'Niell, Walter. 2000. Biosorption and transformation of tetrachloroethene and trichloroethene using mixed species microbial mats. Ph.D. Thesis.

Nzengung, Valentine A., O'Niell, Walter, Wolfe, N.L, Rennels, D.E., McCutcheon, S.C. 2000. Chapter 9: Removal of Halogenated Organic Compounds Dissolved in Water by Algae, Aquatic Plants and Microbial Mats. IN Phytoremediation: Scientific Advances to Manage Contamination by Organic Compounds. Editors: Steven C. McCutcheon and Jerald L. Schnoor (In Preparation 2000.)

O'Niell, Walter and Nzengung, Valentine A. 2000. Treatment of Organic Contaminated water in Microbial Mat Bioreactors. Symposium Series:

Bioremediation and Phytoremediation of Chlorinated and Recalcitrant Organics. Editors: Godage B. Wickramanayake, Arun R. Gavaskar, Bruce C. Alleman, and Victor S. Magar. Battelle Press, Columbus, Ohio. 2(4), Pp 347-252

O'Niell, Walter, Nzengung, Valentine A., Noakes, John, Bender, Judith, Phillips, Peter. 2000. Sorption Accompanied by Biodegradation of PCE and TCE using 
Mixed-Species Microbial Mats. Journal of Hazardous Waste Research. http://www.engg.ksu.edu/HSRC/JHSR/vol2no2.pdf

Walter O'Niell and Nzengung, V.A. 1999. Transformation of tetrachloroethylene and trichloroethylene using mixed species microbial mats under different light intensities. (Accepted as Research Note in Journal of Bioremediation - Under Revision as a Complete manuscript)

Walter O'Niell, Nzengung, V.A., John Noakes, Judith Bender and Peter Phillips. 1998. Biodegradation of PCE and TCE Using Mixed-Species Microbial Mats. IN Bioremediation and Phytoremediation. Editors: G.B. Wickramanayake and Hinchee) Battelle Press, pp 233 - 237.

\section{Oral Presentations}

O'Niell, Walter and Nzengung, Valentine A. 2000. Treatment of Organic Contaminated water in Microbial Mat Bioreactors. Symposium Series: Bioremediation and Phytoremediation of Chlorinated and Recalcitrant Organics. Second International Conference on Remediation of Chlorinated and Recalcitrant Compounds. Monterey, CA, May 2000.

Walter O'Niell, Nzengung, V.A., John Noakes, Judith Bender and Peter Phillips. 1999. Sorption and transformation of tetrachloroethylene and trichloroethylene using mixed species microbial mats. Southeastern Geological Society of America Annual Meeting. Athens, GA March 25 - 27, 1999.

Walter O'Niell, Nzengung, V.A., John Noakes, Judith Bender and Peter Phillips. 1998. Biodegradation of PCE and TCE using mixed-species microbial mats. First International Conference on Remediation of Chlorinated and Recalcitrant Compounds. Monterey, CA, May 18 - 21, 1998.

Walter O'Niell, Nzengung, V.A., John Noakes, Judith Bender and Peter Phillips. 1997. Bioremediation of PCE and TCE using mixed-species microbial mats. Emerging Technologies in Hazardous Waste Management VIII Special Symposium, Pittsburgh, PA, American Chemical Society. 


\section{Project 6: Coastal Wetland Formation and Its Significance to Carbon Sequestration; Y. P. Hsieh, Y. Wang, and L. Robinson}

The main objectives of this study are to assess the rate of coastal wetland formation and its significance to carbon sequestration over the last few decades and to predict its future trends. As sea level rises due to global warming, coastal wetlands are expected to expand landward. We hypothesize that expansion of coastal wetlands in a warmer climate may sequester significant amounts of atmospheric carbon dioxide. If this hypothesis is correct, enhanced carbon sequestration in coastal wetlands would provide a negative feedback to global warming. We have established study sites representing different stages of formation in a coastal wetland in northwest Florida, and have collected a number of soil cores and plants from these sites for carbon and carbon isotopic analyses. Our initial results suggest that Spartina alterniflora (cordgrass) and/or Distichlis spicata were a major component of the coastal wetland during the initial stage of its formation and have since been replaced by Juncus roemeritus (black needlerush). Our initial results also indicate that carbon inventory is much higher in low marsh than in high marsh. We also identified the rate of wetland advancement in the last $50 \mathrm{y}$ due to sea- level rise through archived aerial photographs (Through project consultant, Dr. P. Gong, of the department of ESPM at UC Berkeley). We are in the process of analyzing the radiocarbon contents of soil samples collected from our sites. Radiocarbon data will be used to determine the rates of carbon accumulation and decay in the soils. Following are brief descriptions of the findings of the project to date:

1. Carbon (C), nitrogen $(N)$ and phosphorus $(P)$ in coastal wetland soils:

We have measured carbon, nitrogen and phosphorus content of soil samples collected from low marsh, middle marsh and high marsh, which 
represent different stages of coastal wetland formation. Our data show that soil carbon content is highest in low marsh and lowest in high marsh (Figure 1). This indicates that carbon is being sequestrated into soils as coastal wetland develops from high marsh to low marsh, providing a sink for atmospheric $\mathrm{CO}_{2}$. Previous studies have shown that $30-100 \mathrm{~kg} / \mathrm{m}^{2}$ soil organic carbon (SOC) has been accumulated in coastal wetland area which is ten times that of the adjacent upland soils (Coultas and Hsieh, 1996). In this study, the total soil organic carbon inventory was found to be about $31 \mathrm{~kg} / \mathrm{m}^{2}$ in low marsh, $19 \mathrm{~kg} / \mathrm{m}^{2}$ in middle marsh and $18 \mathrm{~kg} / \mathrm{m}^{2}$ in high marsh. The carbon inventory in low marshes was much higher than in high marshes. That is, as the coastal wetland evolves with time from High marsh (initial stage) to Low marsh (steady-state), carbon sequestration in soils increased significantly. The increased accumulation of SOC is the result of reduced decomposition and increased primary production.

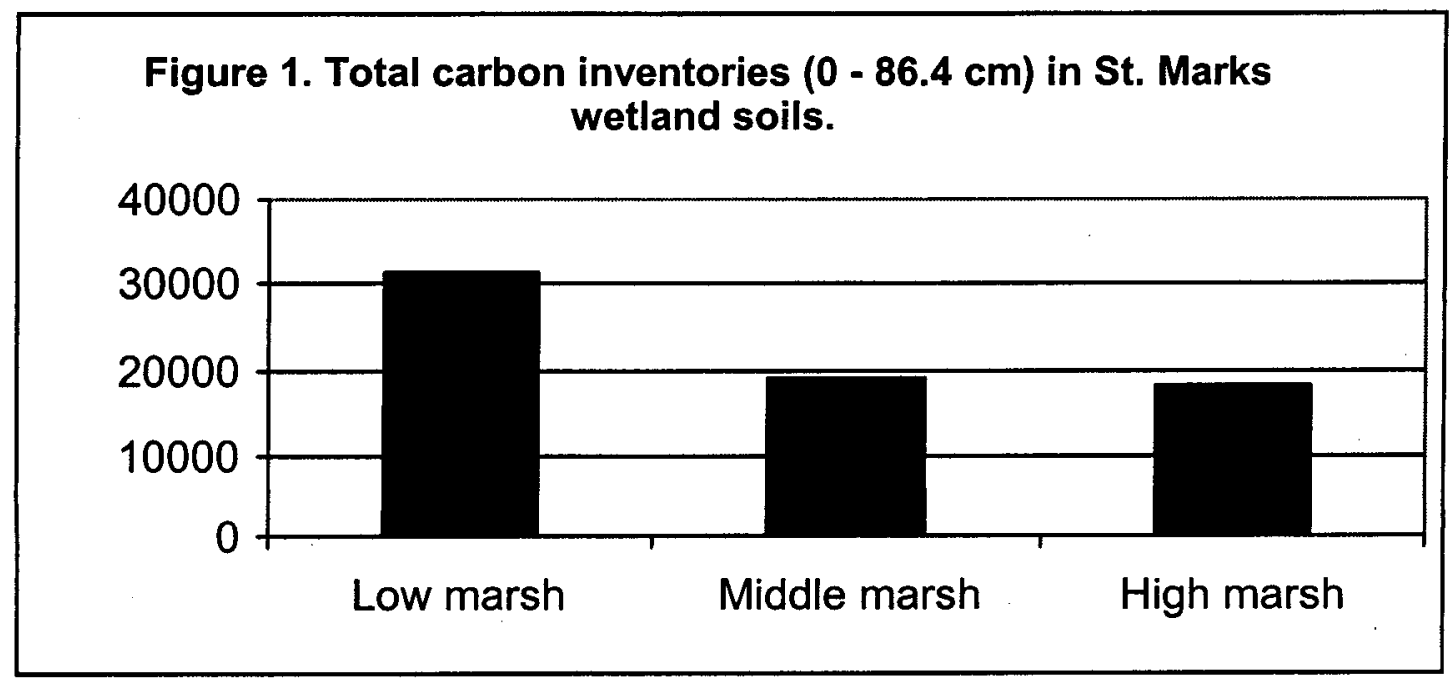

The predominant vegetation in the study area is Juncus roemerianus (black needle rush). J. roemerianus grows best in low marsh area, which has highest soil organic carbon content. Previous research shows that the productivity in St. Marks area decreases landward from $949 \mathrm{~g} / \mathrm{m}^{2} /$ year in the low marsh, to $595 \mathrm{~g} / \mathrm{m}^{2} /$ year in middle marsh, and to $243 \mathrm{~g} / \mathrm{m}^{2} /$ year in high marsh (Krucznski et al., 1978). Soil N, and P contents also show landward decreasing 
from low marsh to high marsh (Fig.2 and Fig.3). This landward change in soil nutrients may well explain differences in productivity.

Figure 2. Total Nitrogen inventories $(0-50 \mathrm{~cm})$ in $\mathrm{S1}$ Marks wetland soils.

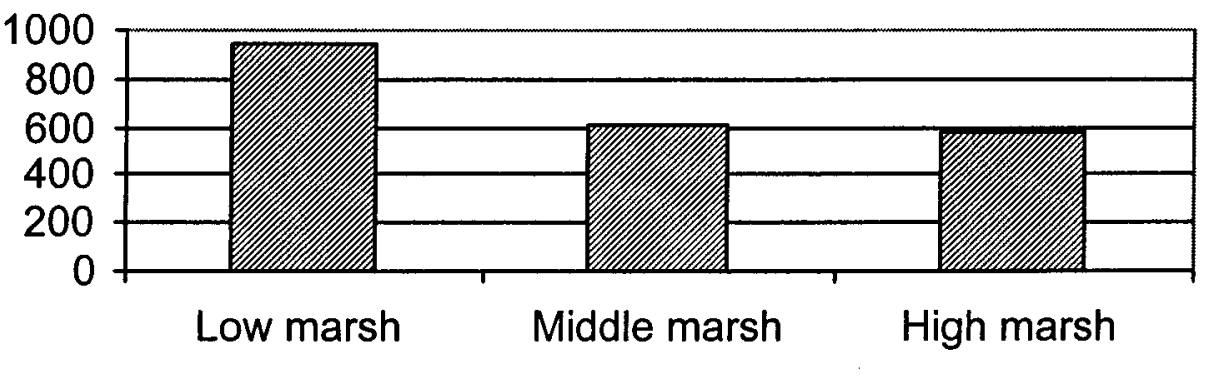

Figure 3. Total Phosphorus inventories
$(0-50 \mathrm{~cm})$ in St. Marks wetland soils.

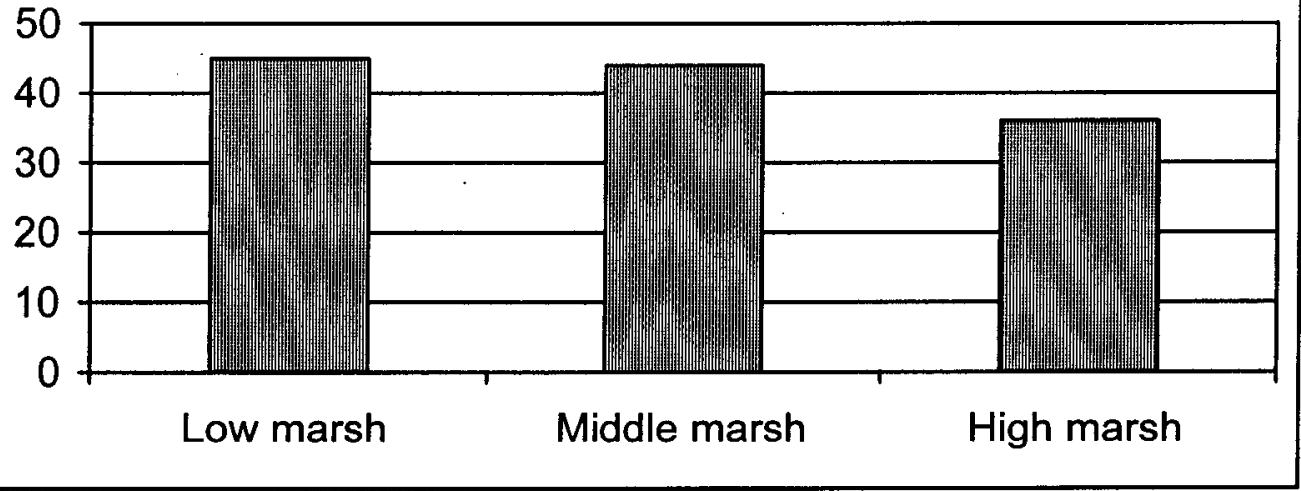

2. Stable isotope results:

The stable carbon isotopic compositions of soil and vegetation samples collected from our study sites were measured. The $\square^{13} \mathrm{C}$ values of soil organic matter from low marsh and middle marsh show little variations $(<4 \%)$ with depth and are consistent with current plant community. However, the $\square^{13} \mathrm{C}$ values of soil organic matter from high marsh vary significantly within the soil profile from $23 \%$ at the surface to about $-17 \%$ at depth. The large $\square^{13} \mathrm{C}$ variations within a single soil profile may be due to any of the following scenarios: 
(1) The $\square^{13} \mathrm{C}$ value of atmospheric $\mathrm{CO}_{2}$ has changed significantly since the beginning of the coastal wetland formation and has affected the $\square{ }^{13} \mathrm{C}$ values of plants over time.

(2) Significant fractionation of carbon isotopes has taken place in the soil as a result of either decomposition processes or differential preservation of plant biochemical components.

(3) The vegetation has changed since significant accumulation of $\mathrm{C}$ began in the soil profile.

Several lines of evidence suggest that the $\square^{13} \mathrm{C}$ value of $\mathrm{CO}_{2}$ in the atmosphere has changed little since the initiation of the wetland formation at the end of the last glaciation. For example, carbon isotopic records from ice cores show that the $\square^{13} \mathrm{C}$ variation in the atmosphere was less than $0.3 \%$ during the last glacial and interglacial cycle (Leuenberger et al., 1992), and was less than 1 $\%$ from 1744 to 1980 (Friedli et al., 1986). Also, if the $\square^{13} \mathrm{C}$ of atmospheric $\mathrm{CO}_{2}$ had indeed changed significantly, this change should have been recorded in soil cores collected from low and middle marshes as well. But soils from low and middle marshes do not show this large $C$ isotopic shift.

As for the second scenario, some studies show that $\square^{13} \mathrm{C}$ value of organic matter from mineral soils is enriched in ${ }^{13} \mathrm{C}$ by $1-3 \%$ with age and increasing depth, suggesting a slight fractionation during decomposition by microbial metabolism (Goh et al., 1976; Goh et al., 1977; O'Brien and Stout, 1978; Schleser and Bertram, 1981; Schleser and Pohling, 1980; Stout et al., 1981; Stout and Rafter, 1978; Stout et al., 1975; Troughton et al., 1974). This is because microorganisms utilize ${ }^{12} \mathrm{C}$ in preference to ${ }^{13} \mathrm{C}$, resulting a slight enrichment in residual organic substrate (Kaplan and Rittenberg, 1964; Rosenfeld and Silverman, 1959). Other studies show that there is little or no isotope fractionation in soils where decomposition is restricted and undecomposed plants accumulate, such as in peats and in New Zealand Agathis soils (Stout et al., 1981; Stout et al., 1975). In general, stable carbon isotopic composition of soil organic matter is compatible to that of source plant material 
and the isotopic fraction during decomposition is less than $3 \%$ (Boutton, 1996; Dzurec et al., 1985; Gulliet et al., 1988; Schwartz et al., 1986).

Because the carbon isotopic composition of atmospheric $\mathrm{CO}_{2}$ has not changed much over time and carbon isotope fractionation during decomposition in soils is small (less than $3 \%$ ), any large difference in carbon isotopic ratios between present vegetation and soil organic matter would indicate that plant species composition (in particular the relative proportion of $\mathrm{C} 3$ and $\mathrm{C} 4$ plants) has changed over time.

Therefore, the $3^{\text {rd }}$ scenario is most plausible for explaining the large $\mathrm{C}$ isotopic difference (6-7\%) in high marsh soils. That is, the large carbon isotopic shift observed in high marsh is most likely caused by a change in local vegetation community.

The coastal wetlands in North Florida are currently dominated by Juncus roemeritus, which is a $\mathrm{C} 3$ plant (using the $\mathrm{C} 3$ or Calvin photosynthetic pathway). However, other species are also present in these wetlands. Carbon isotopic analysis of other plant species from the area show that Spartina alterniflora, Distichlis spicata, and adjacent upland grasses are all C4 plants (using the $\mathrm{C} 4$ or Hatch-Slack photosynthetic pathway), and have $\square^{13} \mathrm{C}$ values ranging from -13 to $-14 \%$. Higher proportion of these $\mathrm{C} 4$ species in local plant community will shift the stable $C$ isotopic ratios of soil organic matter to less negative values. Therefore, the observed $\square^{13} \mathrm{C}$-depth trend in high marsh soils are most likely due to a change in local plant species composition from a C4-dominated ecosystem to a C3-dominated marsh over time. In other words, Spartina alterniflora, and/or Distichlis spicata, and/or upland grasses maybe a major component of the coastal wetland during the initial stage of its formation and have since been replaced by Juncus roemeritus as wetland evolved from high marsh to middle and high marshes.

We are currently preparing a manuscript entitled "Vegetation Succession in a coastal wetland in Northwest Florida: Evidence from stable carbon isotopes". 
The above results of $C$ and stable $C$ isotopic analyses of soils and plants will be presented in this manuscript.

\section{Radiocarbon results:}

We have analyzed some of the soil samples for radiocarbon $\left({ }^{14} \mathrm{C}\right)$ content (Table 1). We are in the process of analyzing rest of the samples for ${ }^{14} \mathrm{C}$ measurements. We are also developing a $\mathrm{C}$ cycle model for wetland soils. This model will be used in conjunction with ${ }^{14} \mathrm{C}$ data to help determine the accumulation rates and residence times of organic carbon in the soils.

4. Rates of wetland landward movement due to sea-level rise in the last $50 \mathrm{y}$.

Figure 4 shows our recent analysis of aerial photographs obtained in 1951 (left) and 1997 (right). Both have been orthorectified using VirtuoZo, a commercially photogrammetric software package available at the Center for Assessment and Monitoring of Forest and Environmental Resources (CAMFER) at University of California, Berkeley. White areas are the salt flats between high marsh and upland forests in St. Marks National Wildlife Refuge $\left(30^{\circ} 5^{\prime} \mathrm{N}, 84^{\circ}\right.$ $\left.10^{\prime} \mathrm{W}\right)$. From the two co-registered orthophotos, we measured that the high marsh proceeded towards the upland by 3-8 $\mathrm{m}$ during the 46 year period as a result of sea level rise. Such phenomena can not be easily measured from coarse resolution satellite remote sensing data.
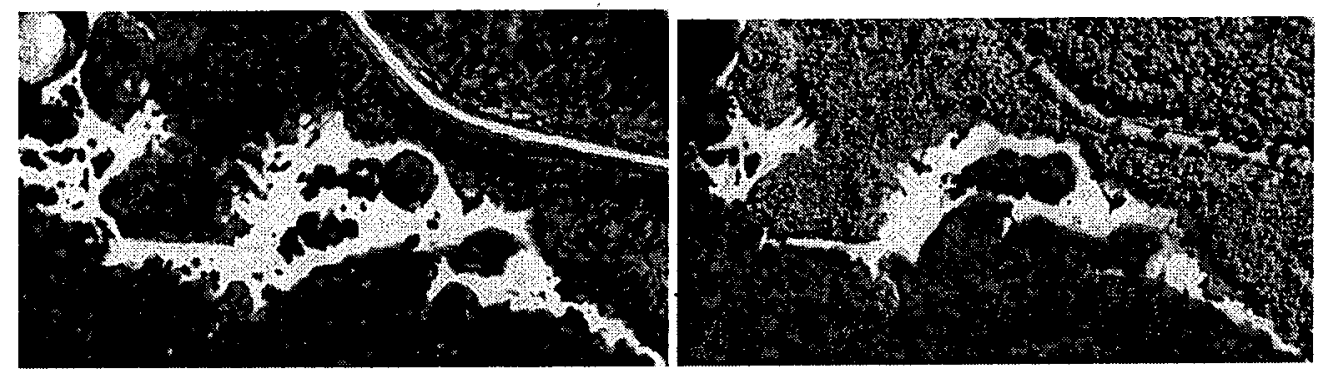

Figure 4. Salt flat change between 1951 (left) and 1997 (right) in St Marks National Wildlife Refuge. The two orthophotos are generated from 1:23,000 aerial photographs. 


\begin{tabular}{|c|c|c|}
\hline & $\begin{array}{c}\text { Depth } \\
\text { (cm) }\end{array}$ & $\Delta^{14} \mathrm{C}(\% 0)$ \\
\hline Low Marsh (1996) & $\begin{array}{c}0-2 \\
2-5 \\
5-10 \\
10-20 \\
20-30 \\
30-40 \\
40-49.5 \\
\end{array}$ & $\begin{array}{c}63.7 \\
115.3 \\
93.7 \\
-15.2 \\
-81.2 \\
-153.3 \\
-206.9 \\
\end{array}$ \\
\hline Middle Marsh (1996) & $\begin{array}{c}0-2 \\
2-5 \\
5-10 \\
10-20 \\
20-30 \\
30-40 \\
40-47.5\end{array}$ & $\begin{array}{c}96.9 \\
145.1 \\
52.0 \\
8.5 \\
\\
-32 \\
-58.5\end{array}$ \\
\hline High Marsh (1996) & $\begin{array}{c}0-2 \\
2-5 \\
5-10 \\
10-20 \\
20-30 \\
30-40 \\
40-50\end{array}$ & $\begin{array}{c}170.6 \\
173.8 \\
48.8 \\
10.9 \\
-11.7 \\
-70.4 \\
-55.1\end{array}$ \\
\hline Low Marsh (1985) & $\begin{array}{c}0-2 \\
2-5 \\
5-10 \\
10-20 \\
\end{array}$ & $\begin{array}{l}135.6 \\
53.9 \\
-2.0 \\
-42.5 \\
\end{array}$ \\
\hline Middle Marsh (1985) & $\begin{array}{c}0-2 \\
2-5 \\
5-10 \\
10-20\end{array}$ & $\begin{array}{c}196.9 \\
102.6 \\
24.1\end{array}$ \\
\hline High Marsh (1985) & $\begin{array}{c}0-2 \\
2-5 \\
5-10 \\
10-20\end{array}$ & $\begin{array}{c}27.1 \\
139.1 \\
123.7 \\
39.5\end{array}$ \\
\hline
\end{tabular}




\section{References}

Boutton T. W. (1996) Stable carbon isotope ratios of soil organic matter and their use as indicators of vegetation and climate change. In Mass spectrometry of soils (ed. T. W. Boutton and S.-i. Yamasaki), pp. 47-82. Marcel Dekker, Inc.

Coultas C. L. and Hsieh Y.-P. (1996) Ecology and Management of Tidal Marshes. St. Lucie Press.

Dzurec R. S., Boutton T. W., Caldwell M. M., and Smith B. N. (1985) Carbon isotope ratios of soil organic matter and their use in assessing community composition changes in Curlew Valley, Utah. Oecologia 66, 17-24.

Friedli H., Loetscher H., Oeschger H., Siegenthaler U., and Stauffer B. (1986) Ice core record of the ${ }^{13} \mathrm{C} /{ }^{12} \mathrm{C}$ ratio of atmospheric $\mathrm{CO}_{2}$ in the past two centuries. Nature 324(6094), 237-238.

Goh K. M., Rafter T. A., Stout J. D., and Walker T. W. (1976) The accumulation of soil organic matter and its carbon isotope content in a chronosequence of soils developed on aeolian sand in New Zealand. Journal of Soil Science 27, 89-100.

Goh K. M., Stout J. D., and Rafter T. A. (1977) Radiocarbon enrichment of soil organic matter fractions in New Zesland soils. Soil Science 123, 385-391.

Guillet B., Faivre P., Mariotti A., and Khobzi J. (1988) The ${ }^{14} \mathrm{C}$ dates and ${ }^{13} \mathrm{C} /{ }^{12} \mathrm{C}$ ratios of soil organic matter as a means of studying the past vegetation in intertropical regions: Examples from Colombia (South America). Palaeogeography, Palaeoclimatology, Palaeoecology 65, 51-58.

Krucznski W. I., Subrahmanyam C. B., and Drake S. H. (1978) Studies on the plant community of a north Florida salt marsh. Bulletin of Marine Science $\mathbf{2 8}$, 316-334. 
Leuenberger M., Siegenthaler U., and Langway C. C. (1992) Carbon isotope composition of atmospheric $\mathrm{CO}_{2}$ during the last ice age from an Antarctic ice core. Nature 357, 488-490.

Schwartz D., Mariotti A., Lanfranchi R., and Guillet B. (1986) ${ }^{13} \mathrm{C} /{ }^{12} \mathrm{C}$ ratios of soil organic matter as indicators of vegetation changes in the Congo. Geoderma 39, 97-103.

\section{ARTICLES IN REVIEW:}

Choi, Y., Wang, Y., Hsieh, Y. and Robinson, L., Carbon sequestration and vegetation succession in a coastal wetland: Evidence from carbon isotopes, Global Biogeochemical Cycles. (Accepted)

\section{ARTICLES IN PREPARATION:}

Wang, Y., Hsieh, Y. P., Landing, W., Choi, Y., and V. Salters, Carbon isotopic evidence for the source and fate of dissolved organic matter in Florida Everglades.

Choi, Y., Wang, Y., Hsieh, Y. and Robinson, L., 2000. The rates of carbon cycling in a coastal wetland in northwest Florida.

\section{ABSTRACTS:}

Choi, Y., Wang, Y., Hsieh, Y. and Robinson, L., 1999. Carbon sequestration and vegetation succession in a coastal wetland in northwest Florida. Spring meeting of American Geophysical Union, Boston. EOS, Transactions (abstract). Vol. 80, p. S116. 
Wang, Y., Hsieh, Y. P., Landing, W. M., Salters, V., Cooper, W. and Proctor, L., 1999. The distribution and carbon isotopic composition of dissolved organic matter in Florida Everglades. The Sixth Symposium on Biogeochemistry of Wetlands (abstract).

Choi, Y., Wang, Y., Hsieh, Y. and Robinson, L., 2000. The rates of carbon cycling in a coastal wetland in northwest Florida. Fall Meeting of American Geophysical Union, San Francisco. EOS, Transactions (abstract).

Wang, Y., Hsieh, Y. P., Landing, Choi, Y., and W. M., Salters, 2000. The source and fate of dissolved organic matter in Florida Everglades. Fall Meeting of American Geophysical Union, San Francisco. EOS, Transactions (abstract). 


\section{Section 3: Outreach, Recruitment and Training Activities}

With the aid of funds from this grant, FAMU faculty and staff organized an extremely popular series of marine science summer camps for high school students. Each year approximately 30 high school students from the Tallahassee area upon recommendation of teachers and selection by faculty and staff would participate in the one-week camp. After the first year of operation the camp was extended to two weeks to accommodate the wishes of student participants. The camp consisted of classroom lectures in environmental and marine science, but focused primarily upon hands-on laboratory and field exercises. Field trips included organized boat tours of Florida's Apalachicola Bay estuary facilitated by scientists at the Apalachicola National Estuary Research Reserve and Florida State University's marine laboratory in Panacea, Florida. Students also visited and studied wetlands and coastal ecosystems in central and south Florida, respectively. Informal tracking of past participants seems to suggest that a large fraction remain interested in science as they pursue undergraduate studies. One student from the 1998 cohort recently enrolled in the environmental science program at FAMU.

In March of 2000 the Environmental Sciences Institute at FAMU hosted the first BIOMP conference. Approximately 50 principal investigators and students attended the meeting which included oral and poster presentations as well as discussions of the fate of programs such as BIOMP.

The first meeting of the Environmental Sciences Institute's advisory since the approval of degree granting programs was held in August 2000 with support from this grant. The two-day meeting and the subsequent input from the committee constituted a critical component of the Institute's self assessment plan. 